\title{
RATE OF RECESSION OF NIAGARA FALLS
}

\author{
BY \\ K. G. GILBERT
}




$$
\begin{aligned}
& \text { BIBRARY } \\
& 186084
\end{aligned}
$$




DEPARTMENT OF THE INTERIOR

CNITED STATES GEOLOGICAL SURVEY

CHARLES D. WALCOTT, DIRECTOR

\section{RATE OF RECESSIOI OF NJAGARA FALLS}

BY :

G. K. GIIBERT

ACCOMPANIED BY A REPORT ON THE SURVEY OF THE CREST BY

W. CARVEI HAII

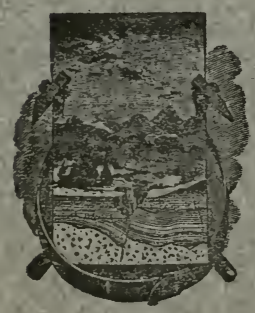

WASHIN GT ON

GOVERNMENT PRINTING OFFICE

1907 

DEPARTMENT OF THE INTERIOR

CNITED STATES (GEOLOGICAL SURVEY

CHARLES D. WALCOTT, DIRECTOR

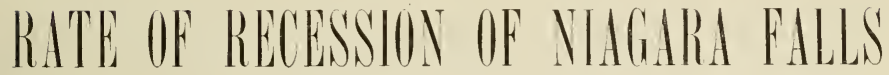

BY

G. K. GILBERT

ACOOMPANIED BY A REPOR'T ON THE SURVEI UF THE CREST

BY

W. CARTHI, HAII

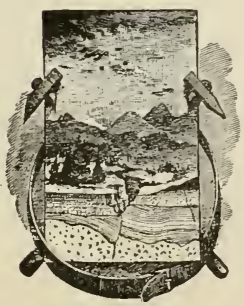

IV A SHINGTON

GOVERNMENT PRINTING OFFICE

1907 



\section{CONTENTS.}

Introduction . . -

The Horseshoe Fall. . . . . . . . . . . . . . . . . . . . . . . . . . . . . . . . . 13

The American Fall . . . . . . .

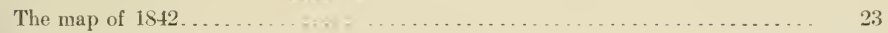

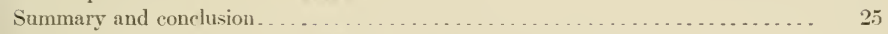

Report of survey of crest line of Niagara Falls, by W. Carve] Hall........... 26

\section{ILLUSTRATIOXS.}

PĹate I. Horseshoe Fall, 1856.

II. Map, crest lines of Niagara Falls in 1812, 1\$75, 1886, 1\$90). and 190.5 . . 10

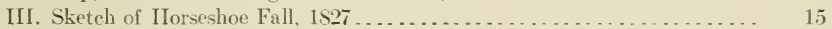

IV. Photograph of Horseshoe Fall, $1595 \ldots \ldots \ldots \ldots \ldots \ldots \ldots \ldots \ldots \ldots . . . \ldots \ldots$

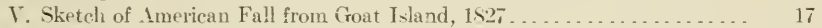

1T. Photograph of Amcrican Fall from Goat Island, $1895 \ldots . . . \ldots \ldots . .17$

VII. Sketch of American Fall from Prospect Point, 182 . . . . . . . . . . . . . 19

V1II. Photograph of American Fali from Prospect Point, 1s95 . . . . . . . . . . 19

IX. American Fall, 15.54 or 18.5, from daguerreotrpe . . . . . . . . . . . 20

X. Eastern part of Horseshoe Fall, about 1855................. 22

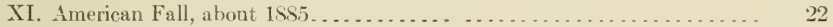

Fig. 1. Diagrammatic profile of Horseshoe Fall. . . . . . . . . . . . . . . . . . . 5

2. Bird's-eve view of Niagara Rirer ........................ 6

3. Map of Niagara gorge ................................. 6

4. Outlines of Horseshoe Fall in 1842, 1875, and $1905 \ldots \ldots \ldots \ldots \ldots \ldots .14$

5. Sketch of American Fall, with lines used in transferring directions..... 20

6. Map of Niagara Falls, with lines of direction ............... 20

7. Plan of American Fall .................................. 21

8. Profile and section of American Fall.................... 23 



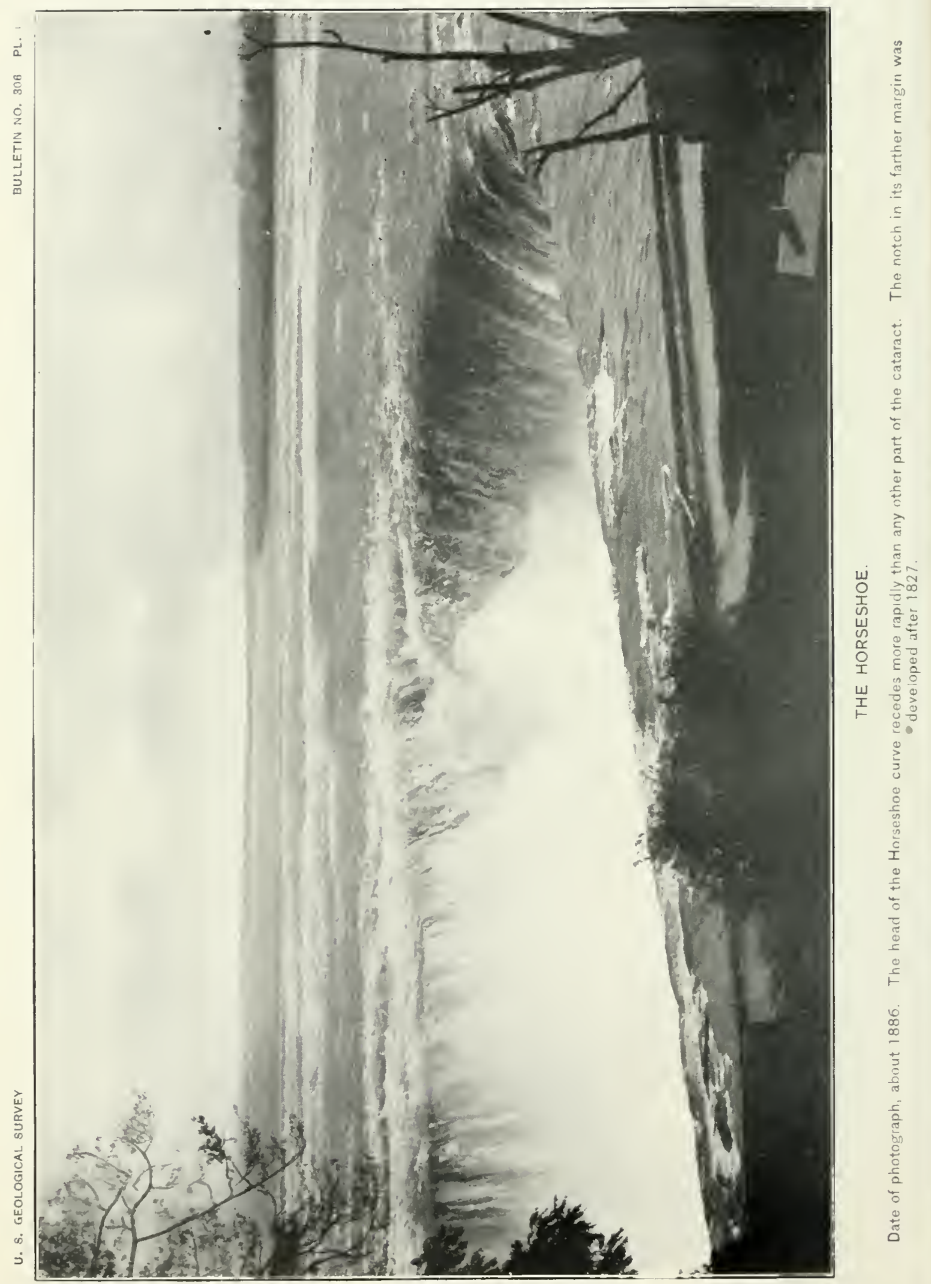




\title{
R.ATE OF RECESSION OF NIAC.ARA FALLS.
}

\author{
By G. K. Gilbert.
}

\section{INTRODLCTION.}

The erosive work of the cataract of Niagara is exceptionally rapid. This depends primarily on the great power of the falling water, but in part on the character of the local geologic structure. The rocks are stratified and lie nearly level. The upper layers are of limestone, strong and resistant; the lower, consisting chiefly of shale, are comparatively weak and yielding. As the shales are worn away below the limestone beds are undermined, so that their edges project like a cornice and are deprived of support. From time to time they rield to the force of their own weight and fall away in large blocks. Each rock fall causes a jar of the ground which is perceived by people in the vicinity, and results in a modification of the crest of the cataract which is readily seen by anyone familiar with its outline. Such changes of the crest have been observed from time to time ever since the neighboring banks of the river were occupied

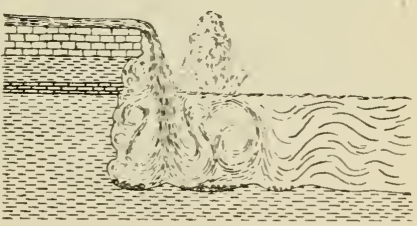

FIG. 1.-Diagrammatic profile of Horseshoe Fall, illustrating mode of erosion and recession. by white men. It is highly probable that they were also observed by Indians before the advent of white men, but on this point I have made no inquiries, as Indian traditions are not likely to be sufficiently definite to aid in determining the rate of progressive change in the position of the cataract.

The surface of Lake Erie is 325 feet higher than the surface of Lake Ontario. The belt of land between them includes two plains, of which the higher and broader is raised but little above the level of Lake Erie, and the lower slopes gently to the shore of Lake Ontario. The descent from the upper to the lower is abrupt, constituting a line of cliffs parallel to the shore of Ontario and known as the Niagara 
escarpment. The river, issuing from Lake Erie at Buffalo. flows at first on the upper plain. It is there broad and comparaticely shallow and has no valley. At the falls it suddenly drops into the head of a narrow gorge which is 6 miles long and extends to the escarpment. Within the gorge it is narrow and contained by steep walls. Near the head of the gorge the water is deep, the current moderate, and the descent small. but farther on are fierce rapids with steep descent. some of these relations are shown in fig. 2. As the falls

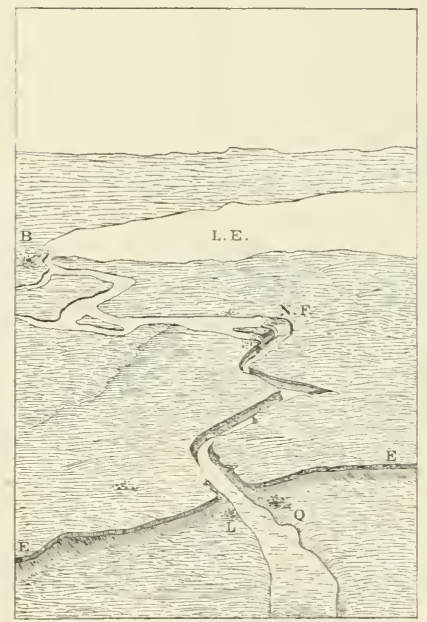

FIG. 2.-Bird's-ere riew of Niagara River. The view is southward, or upstream, from a point above the shore of Lake Ontario, and shows the two plains, the escarpment, and the gorge. B, Bufialo. XF. Niagara Falls. I, Lewiston. Q. Queenston. EE, Niagura escarpment. are at the head of the gorge, it is erident that their recession makes the gorge longer.

Among the early observers of the falls was McCauslin. who remained there from $17 i t$ to 17 $\times 3$. After describing the escarpment at Queenston he says: ${ }^{a}$

It is universally believed that the cataract was originalli at this ridge, and that it has by degrees worn away and broke down the rock for the space of these six or seren miles. Fome hare supposed that from these appearances, ('onjectures might be formed of the age of this part of the world. To enter upon such a calculation, it would previously he necessary to ascertain how much the fall had retired in a hundred years, or any other certain period. Suppose that we were eren in possession of such a fact, still the conclusions drawn from it would be liable to the greatest uncertaint $r$, as it is evident that the space of rock broke down and worn away in a certain number of years would not always be the same. The more or less hardness and brittleness of the rock in different parts: the greater or less sererity of the frosts in different years; and the quantities of water that flowed at different periods in the cataract of the ricer, would all occasion considerable variations. This retrocession of the Falls does not by any means go on so quickly as sone have imagined. During nine rears that I have remained at Niagara, very few pieces of the rock have fallen down which were large enough to make any sensible alteration in the brink: and in the space of two rears $\mathrm{I}$ could not perceive, by a pretty accurate measurement, that the North-East brink had in the least receded. If we adopt the opinion of the Falls haring retired six miles, and if we suppose the world to be 5,700 years old, this will give about sixty-six inches and an half for a year, or sixteen yards and two thirds for nine rears, which I can renture to say has not been the case since $17 i t$.

a McCauslin. Robert, An account of an earthy substance fouud near the Falls of Niagara and rulgarly called the spray of the falls, together with some remarks on the falls: Trans. Am. Philos. Soc., rol. 3, 1793. Read Octoher 16,1759 . The passage cited is on pages $23-24$. 
Enys, who visited the cataract in 1787 , quotes the opinion of residents that "the Falls have altered their position or retreated since the memory of men," a but dissents from the view (which seems also to be generally entertained) that the original situation of the falls was at Queenston.

Weld, whose visit to the falls was in 1796 , says that "even within the memory of many of the present inhabitants of the country, the falls have receded several yards." He farors the theory that the gorge from Lewiston to the falls was maite by the falls, and his discussion of the subject shows him to have been a close observer and clear thinker.

Volney two years later repeats the general statement of observer recession, and adds: ${ }^{c}$

If the European colonists or travellers, to whom this region has been accessible for a century and a half, had made careful memorandums, from time to time, of the state of the fall, we should, by this time, have been able to trace the progress of those revolutions, which are easily proved to have taken place, by restiges and indications which present themselves at every step.

And still further, in a footnote: ${ }^{d}$

It is extremely desirable that the government of the United States, at present under

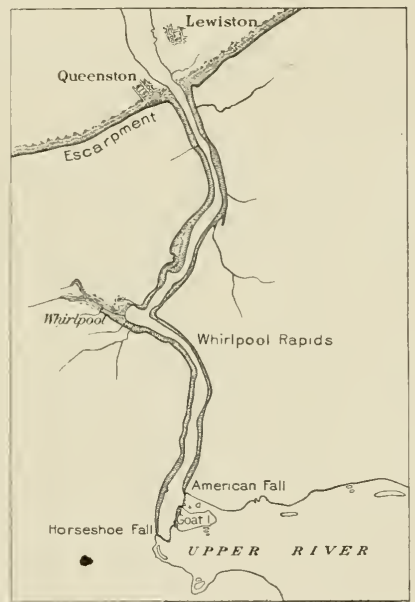

F1G. 3.-Map of the Niagara gorge, showing its relations to the falls and the escarpment. the direction of a friend to the arts and sciences [Jefferson], should order to be drawn up an exact description of the present state of the cataract. This statement, compared with subsequent appearances, observed from time to time, would enable us to trace with certainty the changes that may hereafter take place.

Francis Hall, 1s16, says: ${ }^{e}$

The name of "the Horse shoe," hitherto given to the larger Fall, is no longer applicable: it has become an acute angle. ***. In officer who had been stationed in the neighbourbood thirty years, pointed out to me the alteration which had taken place in the centre of the Fall, which he estimated at about eighteen feet in the thirty years.

$a$ Rept. Canadian Irchives, 1886 (published 1887), p. cexxxii.

$b$ Weld, Isaac,jr., Travels through the States of North America and the Provinees of Upper and Lower Canada during the years 1795,1796 , and 1797 , London, 1799 , p. 320.

cVolney, C. F., A viev of the soil and climate of the United States of America, ete., translated by

C. B. Brown, Philadelphia, 1804, p. 92.

d Op. cit.

e Hall Lieut. Franeis, Travels in Canada, and the United States, in 1816 and 1817, Boston; republished from the London edition by Wells \& Lilly, 1s18, p. 144. 


\section{Gilpin, whose visit was probably a few rears later, says: ${ }^{a}$}

The toe of the shoe, however, is now an angle, rather than a curve: but the inhabitants and early visitors affirm that it was formerly more round, and has gradually assumed its present angular form, within their recollection. * * * Mr. Forssth, who has resided upon the spot for more than forty rears, says, that within his recollection, the centre of this fall has receded from ten to fifteen rards: and, as some intelligent travellers have placed upright a few large stones in frout of the hotel, which, when taken in a line, point exactlr to that spot, it will of course be ascertained, at the end of a certain number of rears, how much this centre recedes annually.

Schoolcraft, whose visit was in 1820 , describes the undermining of the limestone by the fretting away of the shale, and mentions with approral the theory that the falls were anciently at Lewiston. He says: ${ }^{b}$

* * * The wasting effects of the water, and the yielding nature of the rocks, remain the same, and manifest the slow process of a changt, at the present period, as to position, height, form, division of column and other characters, which form the outlines of the great scene: and this change is probably sufficiently rapid in its operation, if minute observations were taken, to imprint a different character upon the Falls, at the close of erery centurr. Nothing in the examination of the geological constitution, and mineral strata of our continent, convers a more striking illustration of its remote antiquity, (still doubted by many) than a consideration of the time, it must hase required for the waters of Diagara, to have worn their channel, for such an immense distance, through the rock. It is true, we are in possession of no cirtain data. for estimating the annual rate of their progress, or for comparing the results with the Mosaic history of the earth. All that can be presumed is, that this progress, is now as rapid, as it was in former ages. ***

Mans and descriptions are now extant, which will enable us to fix the rate of its progress, on the expiration of the present century, and we should not he disappointed in our anticipations, if its progress is found, greatly to exceed the nneralent expectation. To aid in the determination, the Island of Ir which extends from the brink of the Fall, up the river, and which is now connected with the shore, by a wooden bridge, appears to present great. facilities. A simple messurement of its length, with a monument for recording it at its head, would convert it into a graduated scale, and the point of the indentation of the Hurse shoc Fall, could, in like manner, br perpetuated on either shore, by a series of corresponding celestial obserrations, for detcrnining the longitude of the extreme point of that mcurration. Distant ages would thus be furnished with data, the precision of which, would probably enable them to throw new and important lights on the history of the earth, and the changes it has undergone. Is this suggestion of too risionary a nature, to merit the consideration of geological societies?

Capt. Basil Hall, R. M., made a study of the cataract in 1527. and two rears later published an excellent description, from which I quote:c

In the course of our inrestigations and rambles, we met a gentleman who had resided for the last thirty-six vears in this neighborhood-happy mortal! He told us that the Great Horse shoe Fall had, within his memory, gone back forty or fifty yards--that is to sar, the edge, or arch of the rock orer which the watcr poured, had broken down from time to time to that extent. This account was corroborated by that of another gentleman, who had been resident on the spot for forty years.

a Gilpin. H. D.. A northern tour; being a guide to Saratoga, Lake George, Niagara, Canada, Boston. etc., Philadelphia, 1>25. p. 149.

b Schooleraft. Henry R.. Varratire journal of travels, etc., made in 1s20, Albany. 1821, pp. 45-47.

c Hall, Capt. Basil, Travels in North America in the Jears 1827 and 1525, rol. 1, Edinburgh, 1429, pp. $195-197$. 
As these statements came from persons of good authority, I was led to examine the geolugical circumstances more minutely; for I could not conceive it possible, that the mere wearing of the water could perform such rapid changes upon hard lime-stone. The explanation is very simple, however, when the nature of the different strata is attended to. In the first place, they are laid exactly horizontal; the top stratum being a compact calcareous rock. In the next place, I observed, that in proportion as the examination is earried downwards, the strata are found to be less and less indurated, till, at the distance of a hundred feet from the topmost stratum, the rock turns to a sort of loose shale, which crumbles to piees under the touch; and is rapidly worn away by the action of the violent blasts of wind, rising out of the pool into which this enormous cascade is projected.

In process of time, as the lower strata are fairly eaten or worn away, the upper part of the rock must be left without a foundation. But owing to the tough nature of the upper strata, they continue to project a long way over before they break down. There must come periods, however, every now and then, when the overhanging rock, with such an immense load of water on its shoulders, will give way, and the erest, or edge, of the Fall will recede a certain distance. At the time of our visit, the top of the rock, or that over which the river was directed, ovcrhung the base, according to the rough estimate I made, between 35 and 40 feet, thus forming a hollow space, or cave, between the falling water and the face of the rock.

While the above lines were actually in the printer's hands, my eye was accidentally caught by the following paragraph in a newspaper:-

"Niagara Falls. - A letter from a gentleman at that place, dated Dec. 30, 1828, states, that on the Sunday evening preceding, about 9 o'clock, two or three successice shocks or coneussions were felt, the second of which was accompanied by an unusual rushing sound of the waters. The next morning it was discovered, that a large portion of the rock in the bed of the river, at the distance of about two-fifths from the Canada shore to the extreme angle of the Horse Shoe, had broken off, and fallen into the abyss below. The whole aspect of the Falls is said to be much changed by this convulsion. A course of high winds for several days previous to its occurrence, producing an aceumulation of water in the river, is supposed to have been the immediatc cause. This gradual crumbling away of the rock over which the Niagara is precipitated, adds plausibility to the conjecture, that the Falls were once as low down as Lewistown, and have for centuries been travelling up towards their present position."

Captain Hall also published a series of sketches of the falls, ${ }^{a}$ and as these were made with the camera lucida they have exceptional value. They, in fact, constitute the first record bearing on the rate of recession from which measurements can profitably be made, and there is frequent reference to them in other parts of this paper.

The preceding citations serve to show the early development of three ideas: (1) That the crest of the Horseshoe Fall is receding upstream, the recession being caused by the energy of the cataract; (2) that the gorge below the falls was created by this process of recession, the position of the falls having originally been where the mouth of the gorge now is, and (3) that it is possible, by sufficiently accurate observations, to determine the rate at which the change is taking place.

Associated with the idea of measuring the rate of recession was that of applying it to the determination of the time consumed by the river

a Hall, Capt. Basil, Forty etchings, from sketches made with the camera lucida, in North America, in 1827 and 1828, Cadell and Co., Edinburgh, 1829, pls. 1-5. 
in the making of the gorge. By some of the earlier writers the age of the gorge was obscurely connected with the age of the world as estimated from Biblical clata; by others it was recognized as a small fraction of geologic time. With the progress of knowledge of the local geologic history there was increasing interest in the time estimates for the river, and the various conditions affecting the estimate came to be scrutinized with much are. As developed by careful study, the problem proved to be complex and difficult. It came to be recognized not only that the rate of recession in different parts of the gorge must have varied with the height of the cataract, the temporary width of the stream, and the thickness of the capping limestone, which is lifferent in different places, but also in a very important way with the volume of water carried by the river, which has been subject to extreme fluctuations. The influence of these various conditions assumed prominence in the discussion, and altho the rate of present recession came to be fairly well known, opinions still differed widely as to the total period represented by the gorge. The age of the gorge is outside the scope of the present paper, and the subject is here mentioned only to show the basis of the strong interest which has been felt in the determination of the present rate of recession.

In 1s+1 James Hall, then geologist of the fourth district of New York, undertook the preparation of an authoritative map of the crest of the falls, and employed for that purpose E. L. Blackwell, a ciril engineer. The work was completed in the autumn of $18+2$, at which time a series of monuments were established at the principal trigonometric points. The map was published the following rear ${ }^{a}$ together with descriptions of the monuments and a table of compass bearings from the various trigonometric points to objects whose positions were determined by the method of intersection. It was the purpose of this survey to make definite record of the existing position of the crest line and connect this record with permanent monuments, so that by means of a similar surver at some future time the extent of changes might be determined. This purpose it has served. Monuments then placed have been used as starting points in subsequent surveys, and two of them are still extant.

As this work by our great master in geology marks a turning point in the subject - the change from the rague to the lefinite-I quote a few passages to show his point of riew:

Among the phenomena of waterfalls and river gorges, the Cataract of Niagara is justly regarded as holding the first rank, and as standing an index in the path of time, by which the influence of numberless ages upon the surface of our planet may be recorded. Its present, its former and its prospective conditions have engaged the investigation and speculation of many philosophers. The possible consequences of its entire reduction, and the drainage of the upper lakes, have excited the wonder and the apprehensions of many. The 


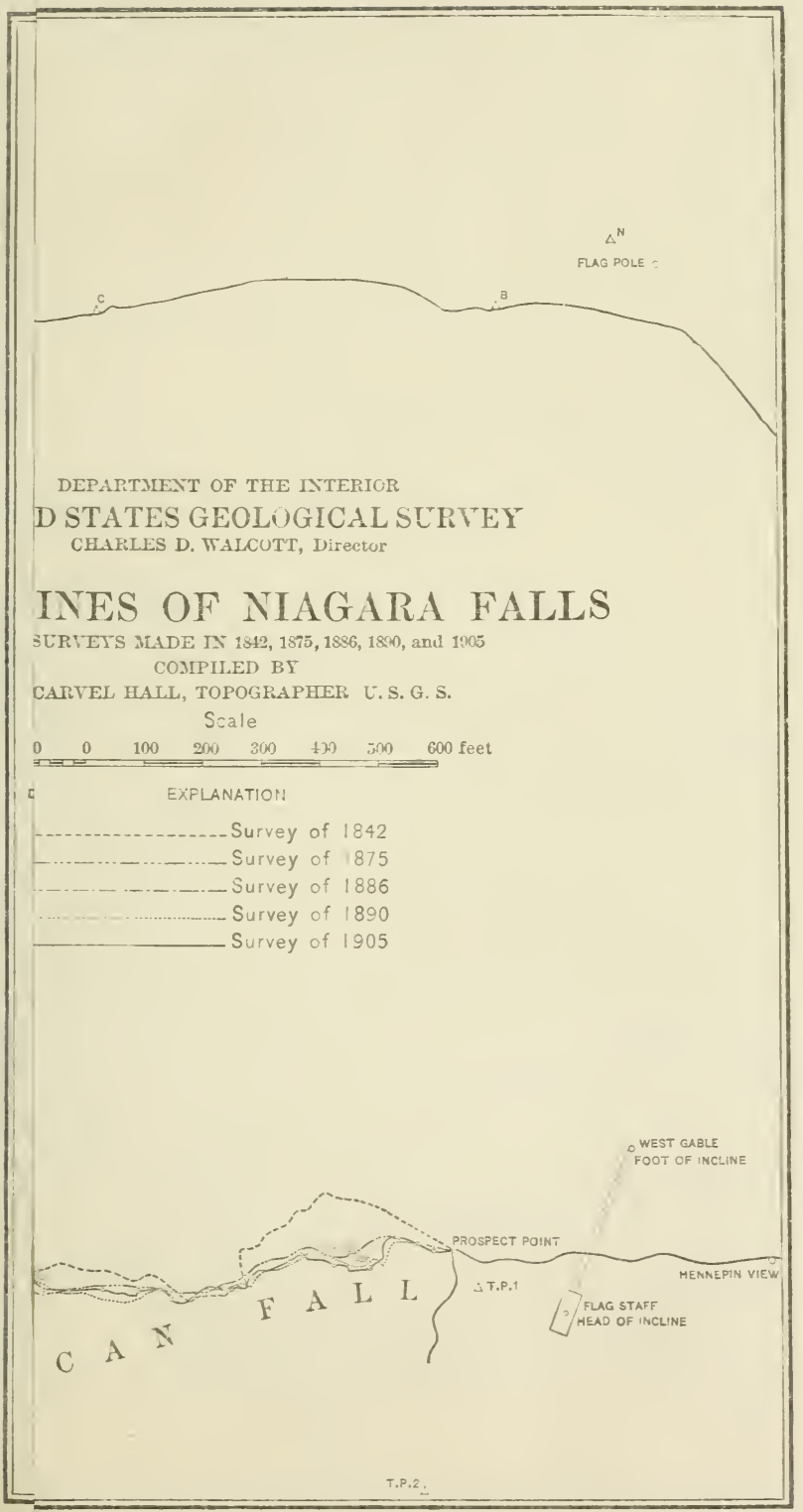




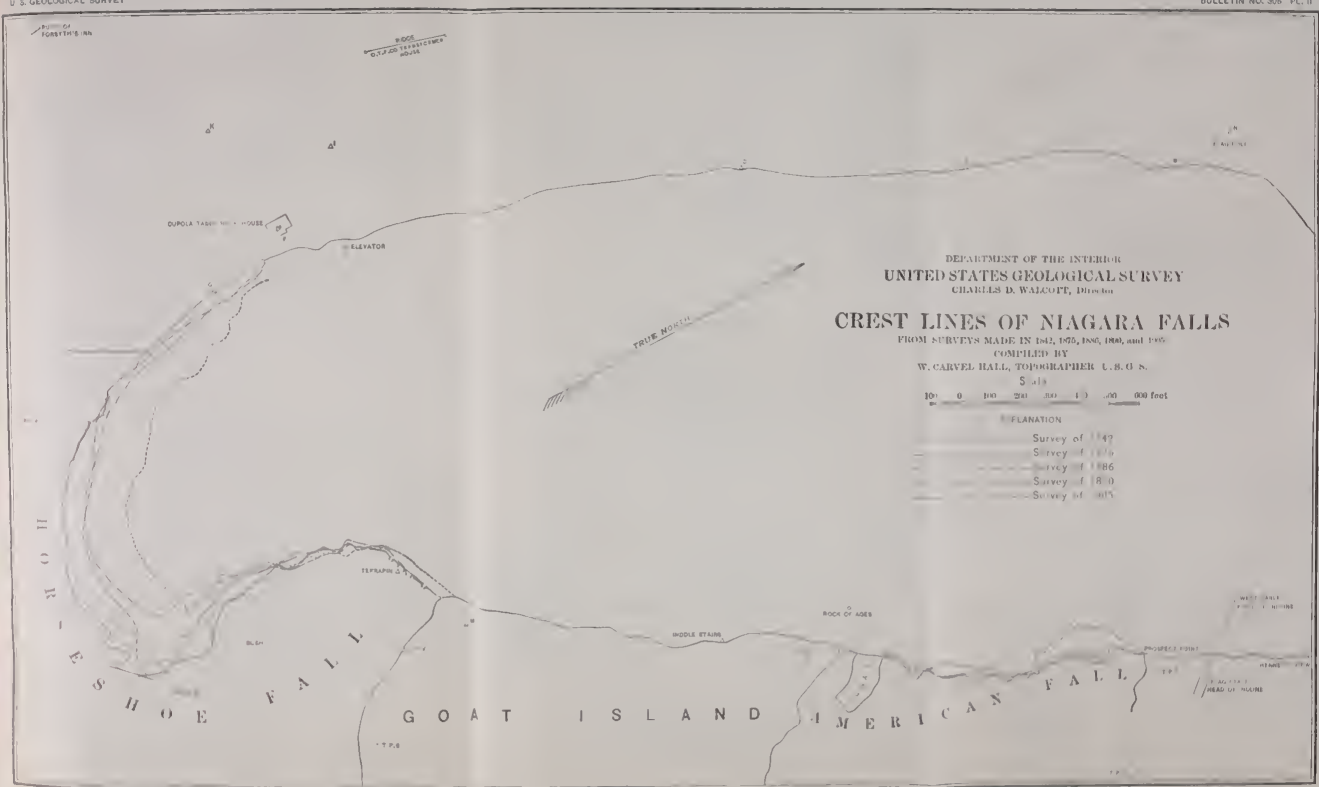


estimated time of its recession has sprinkled grey hairs among the fresh locks of the young and blooning earth, and alarmed those who would consider her still youthful in years.

But amid all these speculations, Niagara still remains; the thunder of its cataract still reverberates through its deep chasms, and its ocean of waters still rolls on as, unknown to the white man, it rolled a thousand years ago. When we come to the investigation of facts, we find that, except to travellers and the aborigines, Niagara was unknown until within the last fifty years; and that even during this time no aecurate observations have been made, $n$ ) monument erected to determine whether the falls are retrograding or not. The testimony of living witnesses and historical evidence unite in confirming the opinion that the water is wearing away the rock, and that the outline of the falls has changed. From these general observations, it has heen estimated that they have receded at the rate of about forty feet in fifty years. Without pretending to question the accuracy of this or any other estimate of the kind, or to establish any rate of retrogression in the falls, we may examine its present, and from numerous facts infer its past condition: and from these we are entitled to draw an inference for the future, though without specifying time. $a$

The foresight with which he planned the survey and record for the specific purpose is shown by the statement with which the map is introduced:

The accompanying map has been constructed from a very careful survey by Mr. Blackwell, giving the present position and outline of both falls, and the river banks upon either side. Upon application to His Excelleney Sir Charles Bagot, late Grovernor-General of Canada, I was authorized to establish monuments upon the Canada shore, and was also kindly offered every other aid to promote the objects of the survey. These monuments, together with those in New-York, will enable future observers to ascertain the amount of recession during any given period. In places where the rock is exposed, copper bolts have been fixed, and in other places hewn stone monuments. The starting point for all these observations is a copper bolt fixed in the rock on the north side, near the edge of the American fall. $* * * b$

In 1875 the second survey of the crest line was made by the United States Lake Survey under the direction of Maj. C. B. Comstock, the field work being by F. M. Towar. The United States Geological Survey undertook the third survey, which was made by Robert $S$. Woodward in 1886 . The fourth survey was made in 1890 , by A. S. Kibbe, under the direction of John Bogart, State engineer of New Iork, and a very full report was published. In this report the maps of the three preceding surveys are republished, and the crest lines given by those surveys are also placed on the new map. ${ }^{c}$ The fifth survey was made in the spring of 1905, by the Lnited States Geological Survey and the State engineer of New York, the work being tone by IV. Carvel Hall, and his report follows this paper.

The crest lines determined by the five successive surveys are plat ted together on Pl. If, and their examination demonstrates clearly the gradual retreat of the crest of the Horseshoe Fall. Each mapped crest line is, on the whole, farther upstream than its predecessor, and

\footnotetext{
a Nat. Hist. New York, pt. 4. Geology, 1843, p. $3 \times 3$.

$b$ Op. cit., p. 402 .

c Seventh Ann. Rept. Comrs. State Res. Niagara for fiscal year Octoler 1, 1ns9, to September 30, 1890, Albany, 1891.
} 
their interspaces are roughly comparable with the time intervals between the making of the surveys; but each of these statements requires qualification. The region of maximum retreat has shifted from one part to another of the crest during the period of observation, so that in any one part the rate of retreat has been irregular; and when the chart is closely scrutinized it is found that the different lines overlap one another at various points, so that if all of them were rigidly accurate their record would show that the crest line had in places advanced downstream, instead of retreating. In the report of the last survey it is suggested that some of these discrepancies may be explained by an actual sliding forward of upper layers of limestone before they toppled orer the brink, but the greater discrepancies can not be explained in this way, and the discrepancies as a whole are unquestionably due to errors in the topographic work, chiefly thru failure to identify points previously sighted when intersecting bearings were taken. Fortunately, they are not of such character or extent as to impair the general conclusions to be Irawn from the work; but they serve to caution the student against any overrefinement in the discussion of results.

The Erie Canal is supplied with water from the Niagara River at Buffalo, the Welland Canal is supplied from Lake Erie, and the Chicago Drainage Canal draws water from Lake Michigan. All the water thus dicerted is withdrawn from the cataract. So also is water diverted from the river above the falls for factory purposes and for use in the generation of electricity. In recent years the diversion for electric power has rapidly increased, and existing charters authorize so large a draft upon the river that it has come to be recognized that the scenic value of the cataract is in peril. A vigorous protest has been made by lovers of natural beauty, and negotiations are in progress for an international agreement to check and regulate the economic exploitation of the river. Whatever the outcome of these negotiations, there is no reason to expect that the natural flow of the river will be restored, and it is believed that from this time onward the natural conditions will be so far interfered with as to modify the rate of recession. As the geologist is primarily interested in the natural rate of recession, the present time is opportune for a summing up of the data. In fact, the survey of 1905 was ordered in view of the change of conditions from natural to artificial. ${ }^{a}$

\footnotetext{
a Since this paper was written it has come to my knowledge that a resurvey of the Niagara River is being made by the C'nited States Lake Survey, the field work for the crest of the falls baving been done in the summer of 1906 . This will afford an additional datum on the rate of recession, but is not likely to affect the computation to a material extent. The addition of one year to the period of observation will probably be offset by changes occurring within that year. Inspecting the Horseshoe curve in August, 1906, I was confident that a salient near the angle of the curve, which was recorded by the surveys of 1890 and 1905 , did not then exist.-G. K. G.
} 


\section{TIIE IIORSESIIOE FALL.}

The Horseshoe Fall is at the head of the gorge. From its edges the walls of the gorge run northeastward approximately parallel. The American Fall is at the side of the gorge, 2,500 feet from its head, and is separated from the Horseshoe Fall by Goat Island. A few hundred years ago the two falls were together, the position of the united cataract being somewhere in the neighborhood of the present American Fall. The subsequent retreat of the Horseshoe Fall has had the effect of lengthening the gorge, but the American Fall has not in the same time marle an alcove in the side of the gorge. With reference therefore to the question of the age of the gorge, it is the Horseshoe Fall whose rate of recession is important.

The chief data for the estimation of the rate of recession are the maps of 1842 and 1905 , the time interval being sixty-three years. The outlines from those maps are shown in fig. 4 . These data, like other statistical data, can be discussed in a variety of ways and made to yield widely divergent results-a fact sufficiently illustrated by earlier estimates of the rate of recession based on comparisons of the map of 1842 with that of $1875,18 \$ 6$, or 1890 . The following paragraphs therefore set forth somewhat fully the methods here used, with the principal considerations on which they are based.

In the lengthening of the gorge the river does its principal work in that part of the Horseshoe curve where the current is deepest. The agitation of the plunging water is there so powerful as to roll about the fallen blocks of limestone, using them as tools to grind the shale, and at the same time breaking them up and eventually washing them downstream. The scour maintains a deep hollow beneath this part of the fall, a hollow whose depth is greater than the height of the fall. (Fig. 1, p. 5.) At the sides of the channel, especially near the right bank, where the sheet of falling water is comparatively thin, the fallen blocks are not cleared away, but cumber the base of the cliff. (Pl. X, p. 22.) As the cataract retreats it leaves behind it a deep channel, or elongated pool, in which the current is slow. Below the cataract the gorge is widened at top by the falling away of its banks. When the shale is exposed to the air it becomes subject to frost action, and for a time the limestone ledge abore continues to be undermined, but a practical limit is reached as soon as the talus of fallen material covers the slopes of shale, and thereafter the change is exceedingly slow. The real lengthening of the gorge is along that portion of the Horseshoe where the sheet of falling water is heavy enough to clear away the débris and maintain a deep pool. The retreat of the cliff on either side of this portion is secondary, and appears to have little or no bearing on the question of the rate at which the gorge is growing longer. I have therefore restricted attention to the central part of the Horseshoe curve. 
As the two erest lines compared are irregular in outline, a certain confusion arises if the recession of different parts is considered separately. At one place the recession seems to have one direction, at another place to have another direction, and various complications ensue when attempt is made to combine measurements made in different clirections. In riew of this difficulty it has appeared to me both convenient and legitimate to assume some one direction as the general direction of recession and at all points measure the amount of recession on lines parallel to that direction. From an inspection of the crest lines as wholes and in their relation to each other I have inferred such a general direction of recession, and assuming it to apply to the entire central tract of the Horseshoe, have drawn the system of parallel lines seen in fig. 4 . There are

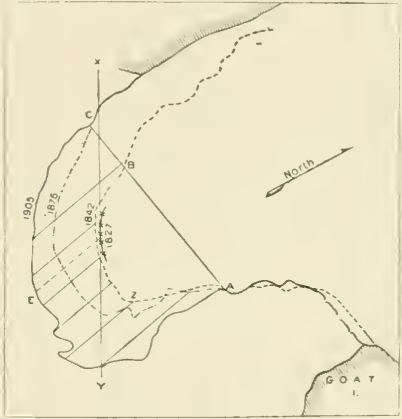

Fig. 4.-Outlines of Horseshoe Fall in 1842, 1875, and 195 , with lines used in computing the rate of recession. The line of erosses suggests a position of part of the crest in 1827 . six of these lines, each extending from the crest line of 1842 to that of 1905 . Their interspaces, according to the scale of the map, are 100 feet wicle. The arerage length of these lines represents approximately the arerage recession of the cataract in the part where the sheet of falling water is heariest. Their lengths are, severally, $430,292,260$, 276,317 , and 412 feet, giving an average length of 331 feet. This distance divided by the number of years, 63 , gives as the average annual recession 5.3 feet.

A somewhat allied method of estimate is concerned with areas. Still restricting attention to the central portion of the Horseshoe curve, I have drawn a line from $A$, the point at which the two crest lines begin to diverge, to the opposite shore at $\mathrm{C}$, making its direction lie at right angles to the general direction of recession. The area contained between the two crest lines $\mathrm{AZB}$ and $\mathrm{AEC}$, and limited downstream by the straight line $\mathrm{AC}$, may be regarded as the area removed by the central portion of the fall between 1842 and 1905. The corresponding width of this part of the gorge in 1842 was $\mathrm{AB}, 570$ feet; in $1905 \mathrm{AC}, 760$ feet. The mean of these, 665 feet, is assumed as the average width for the intervening period. The indicated area between the crest lines was found by measurement to be 223,000 square feet, and this quantity being divided by 665 feet, gives 335 feet as the average recession in a direction at right angles to AC. Dividing, as before, by 63 , the number of years, I obtain again as an estimate of the average annual rate 5.3 feet. 



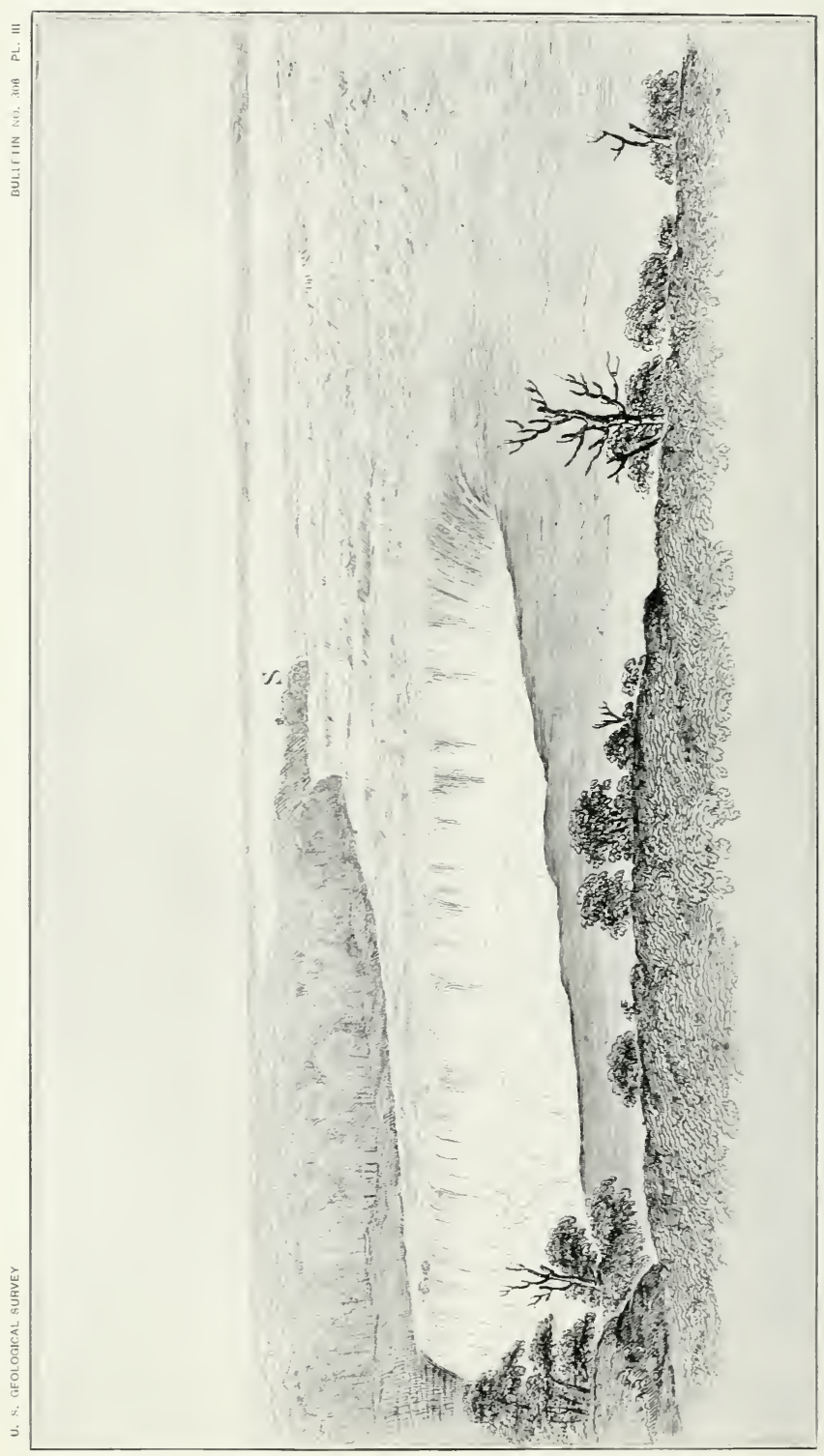

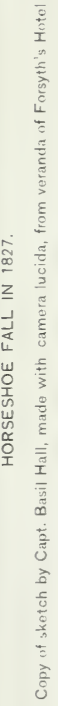




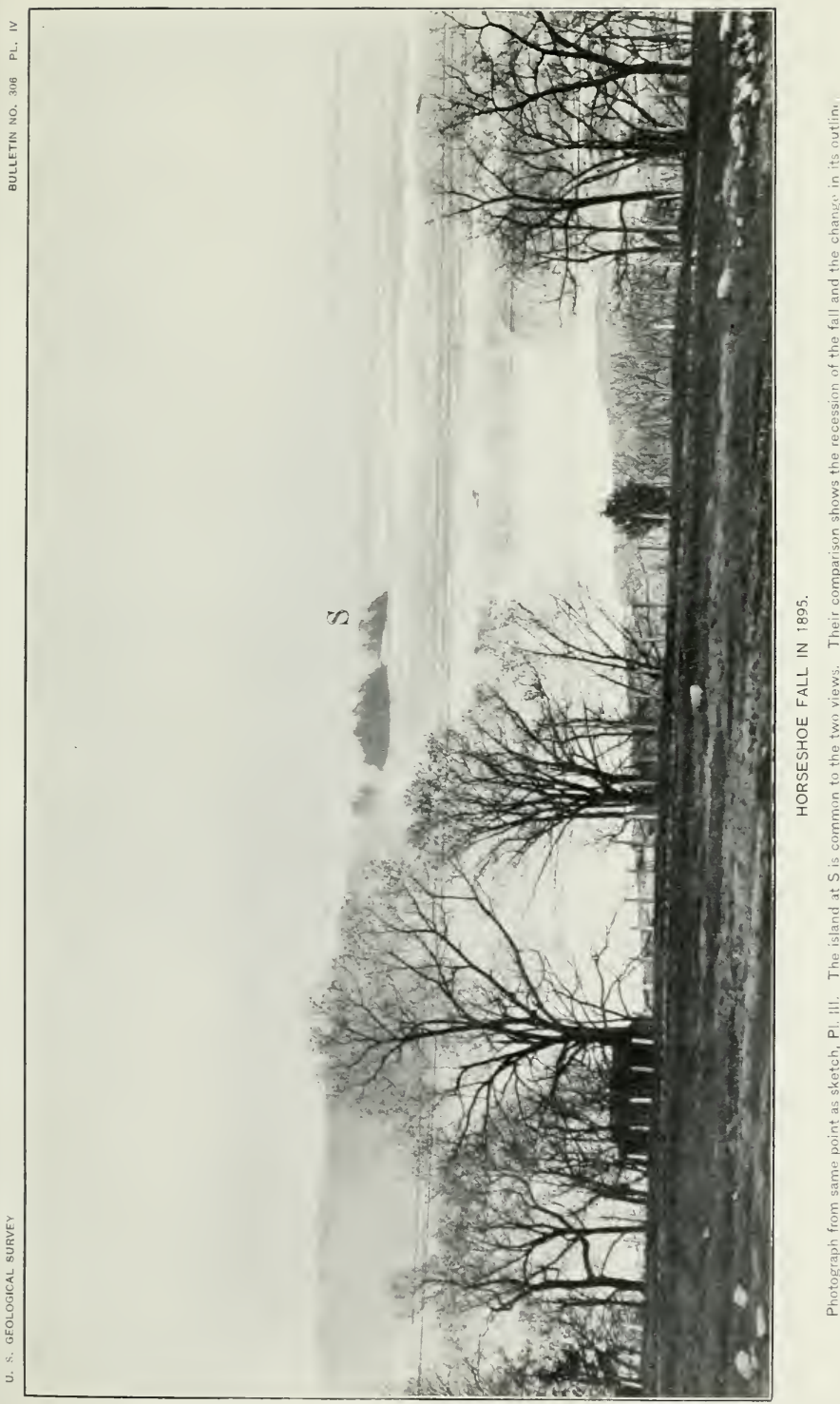



The close coincidence of these two results is accidental, altho a general agreement was to be expected because the assumptions underlying the computations are harmonious. As already stated, materially different results may be obtained with different assumptions.

Less harmonious results are obtained if the period from 1842 to 1905 is divided into parts and the parts are separately computed. Their discordance has two sources which can not be fully discriminated. From the nature of the case the rate of recession is not uniform. The distance to which the cornice of limestone comes to project before it is broken away depends not only on the strength of the rock, but on the local arrangement of vertical joints by which it is traversed, and also to some extent on the shape of the temporary outline of the crest. The fall of rock is therefore irregular and only obscurely rhythmic. In a period measured by centuries these irregularities would have little influence on the general average, but for short periods their influence may be great. A second source of discrepancy in the results lies in the inaceuracy of the surveys. Even where the sheet of water is so thin that the rock is visible thru it there is some liability to error, and where the topographer could see only the curved and changing surface of the rushing water his observations were necessarily somewhat indefinite. Two observers might in fact differ by several feet in their estinate of the actual position of the rock crest over which the water pours. The only results for shorter periods which it seems advantageous to place on record are those which use the maj of 1875 in connection with the maps of 1842 and 1905 . This approximately halves the whole period of sixty-three years, the earlier part being thirty-three years in length and the later part thirty years. By applying to these two divisions the methods already described for the whole period, and employing the same ordinates and the same limiting line, the following results were obtained:

Rates of recession computed for various periods and by different methods.

\begin{tabular}{|c|c|c|c|c|}
\hline & \multirow[b]{2}{*}{ Limiting dates. } & \multirow{2}{*}{$\begin{array}{l}\text { Length } \\
\text { of period. }\end{array}$} & \multicolumn{2}{|c|}{$\begin{array}{l}\text { A verage annual re- } \\
\text { cession. }\end{array}$} \\
\hline & & & $\begin{array}{l}\text { Computed } \\
\text { by parallel } \\
\text { ordinates. }\end{array}$ & $\begin{array}{l}\text { Computed } \\
\text { by areas. }\end{array}$ \\
\hline $\begin{array}{l}1842-1875 . . \\
1875-1905 . . \\
1842-1905 . .\end{array}$ & & $\begin{array}{r}\text { Years. } \\
33 \\
30 \\
63\end{array}$ & $\begin{array}{l}\text { Feet. } \\
\begin{array}{r}4.0 \\
6.6 \\
5.3\end{array}\end{array}$ & $\begin{array}{l}\text { Feet. } \\
\qquad \begin{array}{l}4.4 \\
5.6 \\
5.3\end{array}\end{array}$ \\
\hline
\end{tabular}

The indication is that during the thirty years following 1875 the lengthening of the gorge went on at a somewhat faster rate than during a similar period preceding that date. While it is quite possible that the apparent variation in the rate is sufficiently accounted 
for by the irregularity of the breaking away of the limestone sill, it is also possible that the rate has been influenced by a special condition affecting the mode of recession. A change in the outline of the fall which was mentioned nearly a century ago as diminishing its resemblance to a horseshoe consisted in the development of an angle near the head of the curve and on the side toward Goat Island (Z, fig. 4). Within the last thirty years the recession has been especially rapid in that angle, and there has developed a deep recess or notch. This appears to have been occasioned by a local weakness of the limestone, presumably its subdivision by a belt of vertical joints. Within the notch the mode of recession has been so far modified that the upper layers of limestone have been removed before the lower, so that at certain stages of the process the water after falling from the crest has been caught by a shelf. The configuration can be better understood by an examination of Pl. I (p. 5), which is based on a photograph made in or near the year 1886 . Whatever the method of erosion in the notch, it appears to be superadded to the general erosion by undermining, and an acceleration of the rate may plausibly be ascribed to it.

If we regard the general method of recession by the process of sapping or undermining as normal, and the influence of joint systems as exceptional and temporary, the rate of recession computed for the period from 1842 to 1875 should be accepted as normal and the best available for use in geologic computations; but this involves the assumption that the limestone ledge was not affected in other parts of the gorge by belts of weakness similar to the one which has been exposed during the last few decades. It seems to me better, on the whole, to assume that the limestone eroded between 1842 and 1905 is fairly representative, so far as strength is concerned, of all that portion of the limestone ledge in which the cataract has done its work.

The maps of 1842 and 1905 represent the earliest and latest surveys, but do not include quite all the data worthy of consideration in this connection. A sketch by Basil Hall, made with the aid of a camera lucida, in 1827 , has a claim for accuracy by no means to be disregarded. In the use of the camera lucida the draftsman sees the landscape as tho faintly pictured on a sheet of paper, and at the same time sees the pencil with which he traces its outlines. Before photography this method was the most accurate known for recording the outlines of a landscape, and in skilful hands it gives results of notable precision. There is much internal evidence that Captain Hall's sketches at Niagara were made with care and fidelity, and in view of these facts I have thought it worth while to endearor to combine his record with the records by mapping. He tells us that his principal sketch of the Iforseshoe Fall (PI. III) was made from the upper reranda of Forsyth's Inn, on the Canadian shore, and the relation of the veranda to the inn is shown by a contemporary drawing by Mrs. 



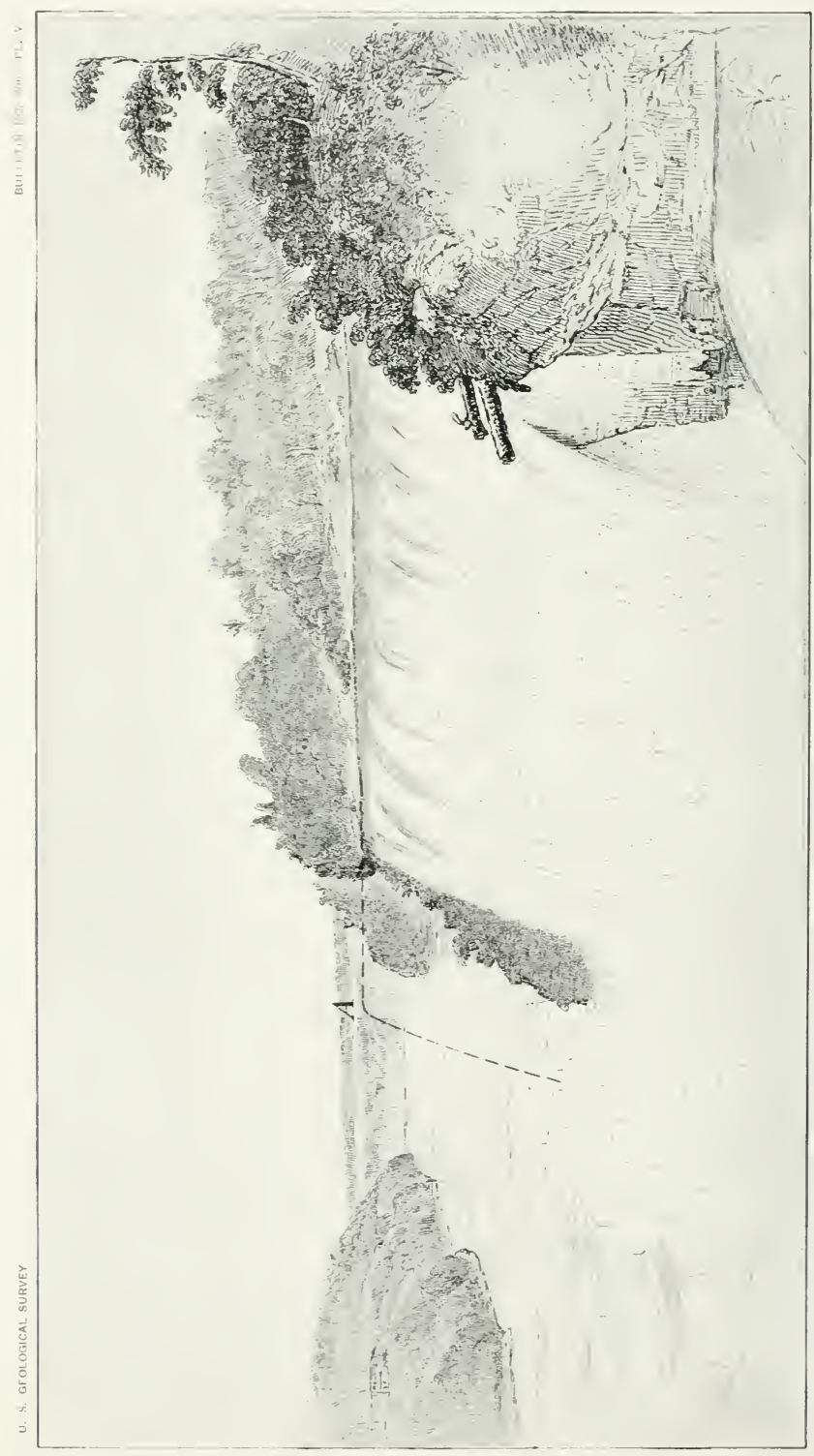

2
$\vdots$
$z$
$z$
$z$
$\bar{z}$
$z$
$z$
0
0 


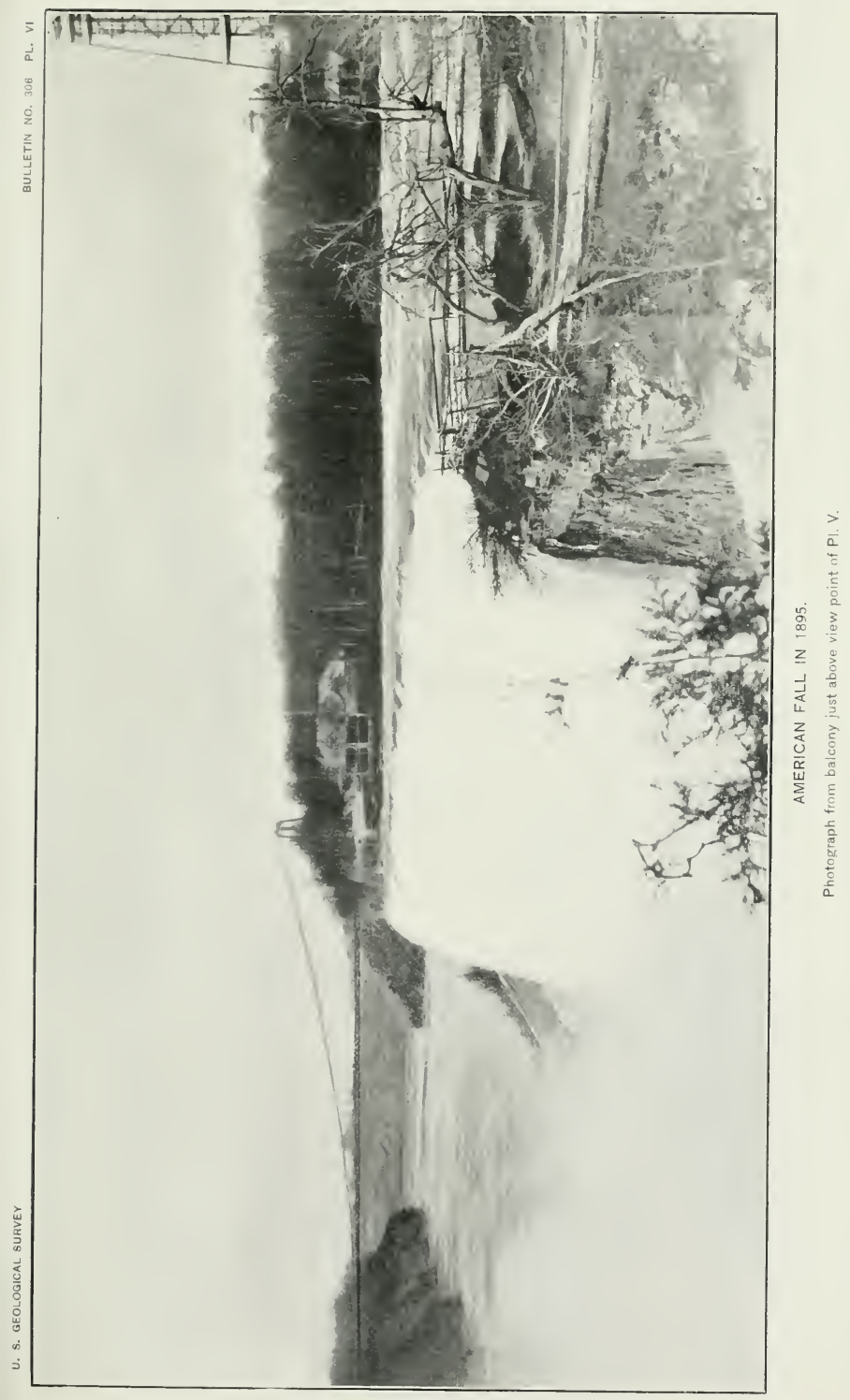



Trollope. ${ }^{a}$ The inn itself long since disappeared, but its position is still marked by the ruins of its foundations. Thru the courtesy of Mr. James Wilson, superintendent of Victoria Park, who caused the necessary scaffolding to be constructed, I was enabled, in 1895 , to place a photographic camera within a few feet of the position once occupied by the camera lucida, and this position has also been located on the map of 1905 (Pl. II, p. 10). A comparison of the two pictures made from that position yielded the identification of a common point on one of the Three Sister Islands (S, Pl. III), and with the aid of the orientation thus secured it became possible to draw upon the modern map the line XY in fig. 4, representing a direction from Captain Hall's point of view tangent to the head of the Horseshoe Fall. It will be observed that this line passes very near to the head of the curve as drawn in the map of 1842 , the implication being that at the head of the gorge very little recession had occurred in the fifteen years interrening between 1827 and 1842 . I am not sure that this single line, obtained by so circuitous a method, should be allowed to influence the result based on two topographic surveys, but to whatever extent it is given consideration its tendency is to reduce the estimate of the annual rate.

\section{TIIE AMERICAN FALL.}

The recession of the American Fall is much slower than that of the Horseshoe. The sheet of water on its brink is comparatively thin, and the force the water acquires in falling is not sufficient to remove the larger of the limestone blocks broken from the ledge above. The blocks are therefore heaped at the base of the cliff and serve as a natural riprap to protect the shale against wear. (See Pl. XI, p. 22, and fig. S, p. 23.) Since the Horseshoe Fall parted from the American, leaving it stranded at the side of the gorge, there has evidently been some falling away of the crest of the American Fall, else there would be no limestone blocks at its base. But as the talus increases in height it becomes more and more protective, and the rate of recession should theoretically diminish.

It has already been observed that the geologist's interest in the rate of recession applies primarily to the Horseshoe Fall, because the work of that fall makes the gorge longer. If the conditions of erosion had been uniform during the whole period of the excavation of the gorge the work of the American Fall would have little bearing on its time estimates, but the volume of the river has not always been so great as at present, and there were two epochs in the history of the gorge when the volume was very small. During those epochs the discharge of the whole river was probably not much greater than the present discharge thru the American channel, so that the conditions

a Trollope, Mrs., Domestic manners of the Americans, vol. 2, London, 1832, frontispiece.

Bull. $306-06-2$ 
affecting erosion were somewhat similar to those illustrated by the American Fall. For this reason it is worth while to inquire at what rate the American Fall has receded since the first precise observations on its position and contour.

Traditional information as to changes in the American Fall is summarized by Lyell: ${ }^{a}$

The sudden descent of huge rocky fragments of the undermined limestone at the Horseshoe Fall, in 182S, and another at the American Fall, in 1818, are said to have shaken the adjacent country like an earthquake. According to the statement of our guide in 1841 , Samuel Hooker, an indentation of about forty feet has been produced in the middle of the ledge of limestone at the lesser fall since the rear 1815 , so that it has begun to assume the shape of a crescent, while within the same period the Horseshoe Fall has been altered so as less to deserve its name.

The graphic record begins with two camera lucida sketches by Basil Hall, made in 1827. One was from Goat Island, near the southern end of the crest line, the other from a point on the Imerican shore near the northern end of the crest line. His view points were so near to the fall that he was able to represent details too small to appear in the sketch of the Horseshoe Fall. The American Fall was also mapped with the same care as the Horseshoe in $1842,1875,1856$, 1890 , and 1905. Since the time of the daguerreotype the fall has been photographed from positions similar to those occupied by Basil Hall, and in 1895 I recovered his viewpoints as nearly as practicable for the sake of making photographs which might be compared with his camera-lucida sketches. To this end I visited the localities with his sketches in hand, and endearored to determine the riew points by comparing various details of the sketches with the landscape before me. His sketches and the photographs are compared in Pls. V-VI and VII-VIII.

Examination of the combined map in Pl. II (p. 10) shows that the outlines recorded in $1875,18 \$ 6,1890$, and 1905 run closely together, the plotted lines intersecting one another at rarious points, while the line of $18+2$ coincides for only a part of the distance. A broad projection near the northern shore is indicated by the map of 1842 only, and that map also gives a more advanced position for the middle part of the crest line.

There is good reason to question the accuracy of the map of 1842, especially in the vicinity of the northern shore. The area there indicated outside the line of 1875 and later maps is 110 feet broad. As its position is close to Prospect Point, which has been a popular view point thru the entire period under consideration, the falling away of such a body of rock, either gradually or all at once, could not have escaped notice, but (so far as my reading goes) current literature, including the literature of the guidebooks, is silent in regard to it. In 



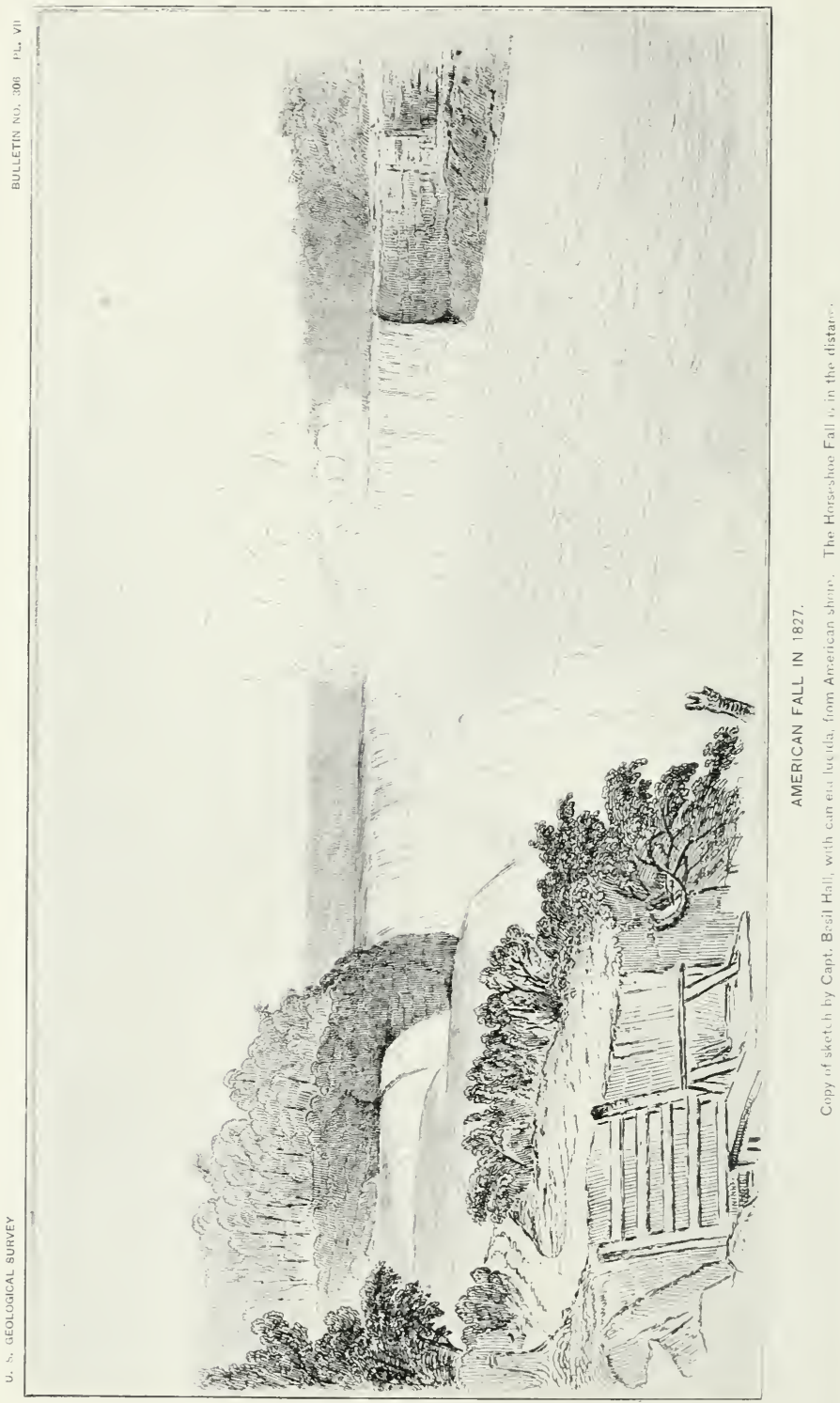




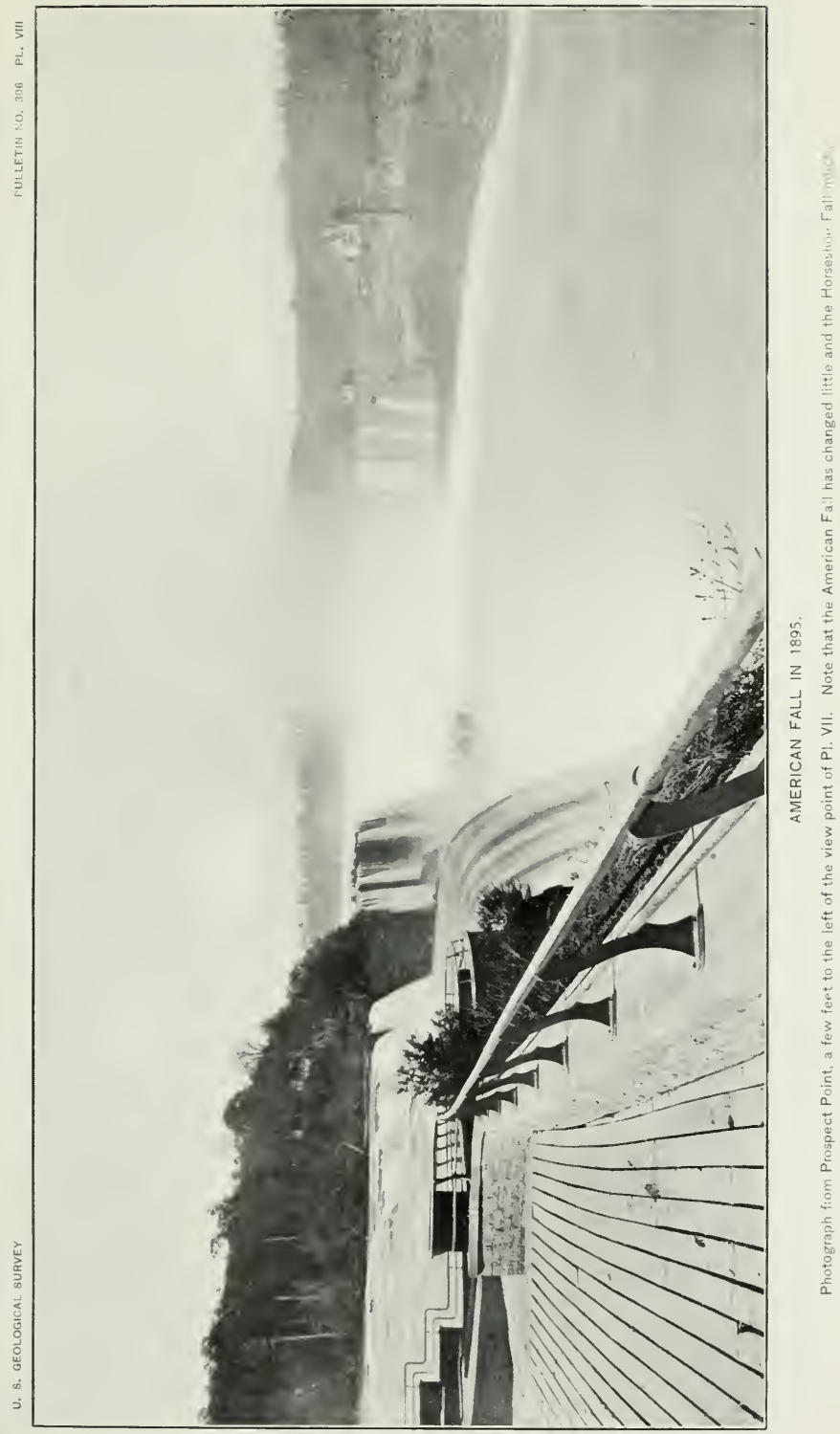



addition to this negative evidence, there is positive information in the Basil Hall sketches. Comparing his sketch from Goat Island (Pl. V) with my photograph made from approximately the same point in 18:5 (Pl. VI), it will be seen that there is essential correspondence in the distant headlands along the river. By means of these headlands I was enabled not only to establish a definite relation between the two views, but also to correlate the sketch of 1827 with the map of the gorge made in 187.5 , and by the aid of that map with the various charts of the crest line. Thru these comparisons it is shown that if the crest line in 1827 had had the form indicated by the map of 1842 , its profile would have the position indicated by the dotted line $A$ in $\mathrm{Pl} . \mathrm{V}$, and the cataract would conceal the eastern half of the gorge vista. If the great salient did not exist in 1827 , it could not have existed in 1842. The conclusion appears unavoidable that the map of 1842 is wholly erroneous in its delineation of that part of the crest line near Prospect Point.

As the Basil Hall sketches have thus served to discredit a portion of the map of 1842 , it is in order to inquire whether they afford a substitute for the evidence ruled out. Once more using the vista down the gorge as the basis of correlation, and applying measurement to points recognized as identical, I have ascertained that the sketch of 1827 and the photograph of 1895 give to the extreme salient of the American Fall almost identically the same position. At that particular point the recession appears to be zero. Nearer than the salient, and appearing about one-fourth inch to the right of it, is a peculiar configuration of the crest line which seems to be common to the two views. In the photograph a dark wedge projects obliquely downward and toward the left, intermupting the body of white. In the sketch its position is occupied by a sweeping curve, less angular than the other lines representing the turn of the water. Making proper allowance for the fact that the water was unusually low in the summer of 1895 , I think it quite possible that these features of the two pictures represent the same local and peculiar configuration of the rock of the crest, and the suggestion they give is that there has been no change whatever in the crest line of that portion of the American Fall since 1827 .

The earliest good daguerreotype of the American Fall to which I have been able to assign a date is reproduced in PI. IX. The gentleman who loaned me the daguerreotype appears in the picture as a child, and was able by that circumstance to fortify his memory and say that the view was taken in 1854 or 1855 . Close 'comparison of the daguerreotype with the photograph reproduced in Pl. VIII, shows a large number of identical details ranged along the crest from the deepest reentrant to Luna Island, and proves that there was practically no recession in that part of the American Fall in the forty years from 1855 to 1895 . 
In Basil Hall's riew from the American shore (Pl. VII) a number of points are sufficiently definite to be used in correlating the sketch with the map. Forsith's Hotel appears on the bluff at the extreme

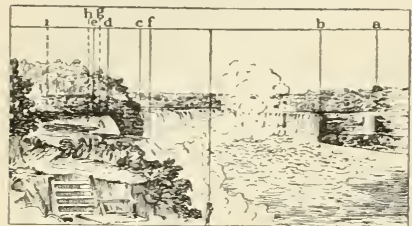

F1G. 5.-Basil Hall's sketch of American Fall from Prospect Point, with lines used in transferring its directions to map. Compare figs. 6 and $\tau$ and Pls. VII and VIII.

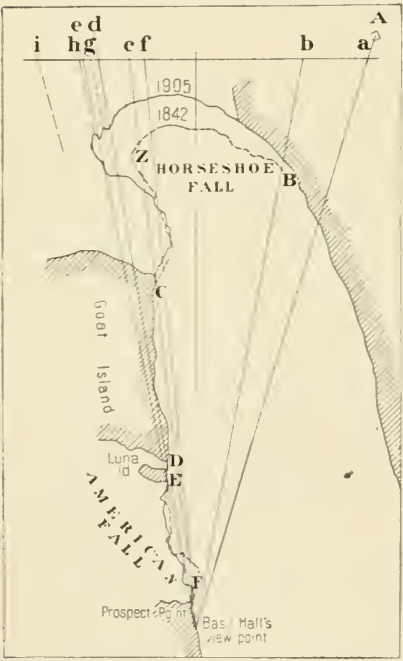

F1G. 6.-Map of Niagara Falls, with lines drawn to rarious points from the point occupied by Basil Hall in making a camera lucida sketch. Compare figs. 5 and $\tau$ and Pl. Vil. A, Forsyth's hotel; B, western edge of Horseshoe Fall; C, profile of Goat Island cliff: D, erest of American Fall at Goat 1sland; E, crest of American Fall at Luna 1sland; F, extreme salient on crest of American Fall. horizontal direction of the object from the riewpoint. In order to show clearly the relations of the directions of the various objects, I drew from them a series of rertical lines by which their posiHorseshoe Fall holds the same position as in 1842 . The eastern edge of the Horseshoe Fall, or the righthand profile of Goat Island, serves as another identification point, altho it has doubtless fallen away a few feet. The crest of the American Fall where it adjoins Goat Island and its interruption by Luna Island are somewhat indefinite objects by reason of the currature of the water profile, but are nevertheless serviceable, especially as their stability is assured by the general agreement of records. The nearer profile of the American Fall is assumed on the evidence just cited to have the position assigned it by the maps of 1890 and 1905 . These points all appear on the map (Pl. II, p. 10). The approximate position of the artist's riewpoint is suggested by the foreground, taken in connection with various allusions in the literature.

As the geometric method of making comparison between a picture and a map may not be familiar to all readers of this paper, I venture to explain the procedure in this case, adding that similar methods were employed in other comparisons to which allusion has already been made. It is erident that the distance of any object in the view, fig. 5 , to the right or left of a central vertical line depends on the right. The western edge of the 

tions were projected against a horizontal line near the top of the sketch. Lines were also drawn on the map, fig. 6, from the assumed viewpoint to the corresponding oljects, and an additional line was drawn in the general direction corresponding to the middle of the picture. Then at right angles to the last-mentioned line, and at a suitable distance ascertained by trial, a line was drawn intersecting all the direction lines. The map gives the projection of the various points on a horizontal plane; the sketch gives their projection on a vertical plane. The line last drawn represents the intersection of these two planes of projection. If the map and sketch are both accurate, then the points $a, b, c$, etc., on the map should be separated by the same spaces as the points $a, b, c$, etc., at top of the sketch. As a result of the trial a very close agreement was found-as close an agreement as could be expected in riew of the indefiniteness of some of the points. This agreement serres to verify the determination of the riewpoint, and-also to support the conclusion that the criticism preriously made of the map of 1842 is valid.

Having thus established the relation of the sketch to the map, it was possible to transfer the directions of other points of the sketch to the map. Two reentrants and one salient of the fall were projected upward on the sketch, giving the points $g, h$, and $i$. These were transferred to the line on the map representing the intersection of projections, and lines were drawn

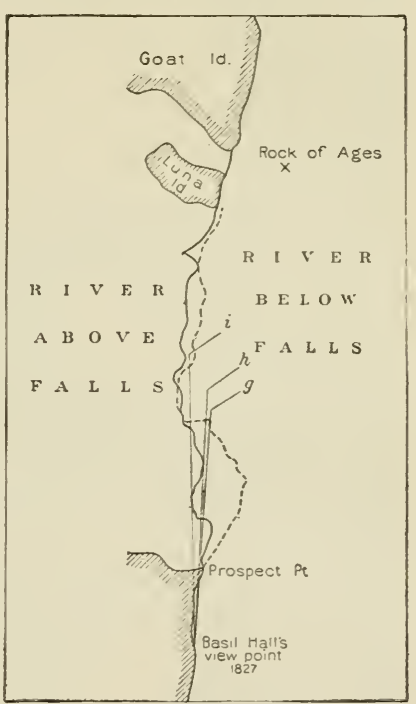

Fig. 7.-Plan or American Fall. A full line shows the crest as mapped in 1905; the broken line, as mapped in 1842: $i$, tangent to deepest reentrant as sketched by Basil Hall in 1827; $h$, tangent to reent rant nearer Prospect Point 152 ; $g$, tangent to salient between two reentrants, $1 \times 2 \tau$. Compare figs. 5 and 6 and PI.VII.

from them to the riewpoint. These last-mentioned lines indicate on the map the directions of the corresponding features as recorded by the sketch of $182 \pi$, but do not show their distances from the viewpoint. They do not fix on the map the positions of the salient and reentrants, but assign certain limits to be observed in any attempt to chart the crest line as it was in 1827 . They are represented on a larger scale in fig. 7. In a general way they indicate that there has been a small amount of recession since 1827 in various parts of the crest line. Such an inference, however, should not be 
made without qualification, because the indicaterl amount of recession is of the same order of magnitude as the errors of survey and other imperfections of the data.

To give the matter quantitative statement I have tried the experiment of assuming as correct the map of 1905 and the limitations inferred from the sketches of 1827 , and then interpreting other data in such way as to afford the greatest plausible recession. A computation based on these assumptions gives an average total recession since 1827 of 19.7 feet and an arerage annual recession of 0.25 foot. This I regard as a maximum estimate. It is highly probable that the actual average rate of recession is less than this, and it may be much less. The idea that it is much less finds support in the identical appearance of one part of the crest in 18.55 and 1905 and in the apparent identity of another part in 1827 and 1895 .

The matter can be approached in another way. The distance thru which the Horseshoe Fall has retreated since it parted from the American Fall is about 2,500 feet. Allowing 5 feet per annum as the rate of recession, the parting took place about five hundred years ago. The condition of the American Fall at the time of separation may be inferred in a general way from an examination of the eastern part of the Horseshoe Fall at the present time ( $\mathrm{Pl} . \mathrm{X})$. From Goat Island to a point about 500 feet westward the water is shallow, correesponding in arerage depth to that of the American Fall. Beyond that point it is comparatively deep. In the region of deep water the recession of the cataract is rapid, and the portion with shallow water is being left behind. At the base of that part of the fall where the water is shallow the descending stream does not plunge into the pool, but strikes a talus of rock fragments. These fragments are in part visible, and their existence is elsewhere inferred from the forms given to the spray by the reaction. It seems to me legitimate to infer that the American Fall at the time of its abandonment by the Horseshoe was not so adranced in position as to plunge into standing water, but had alreacly retreated far enough to have acquired a talus above the level of the pool. At the present time the profile of the American Fall where its volume of water is greatest is approximately as shown in fig. $\$$. The edge of the main river is at $\$, 220$ feet horizontally from the crest of the fall at $\mathrm{C}$, the interrening space being occupied by a gently sloping talus of large limestone blocks, among which the water descends in a labyrinth of cascarling torrents (Pl. XI). At the initial stage, when the American Fall was first separated, the position of its crest was probably at some point (I) between its present position and the outer edge of the risible talus. As sketched, I is 160 feet from $\mathrm{C}$, and if the total retreat of the American Fall in five hundred years was 160 feet the arerage rate of recession was 0.32 foot per annum. Allowance should be made for difference in rate dependent 


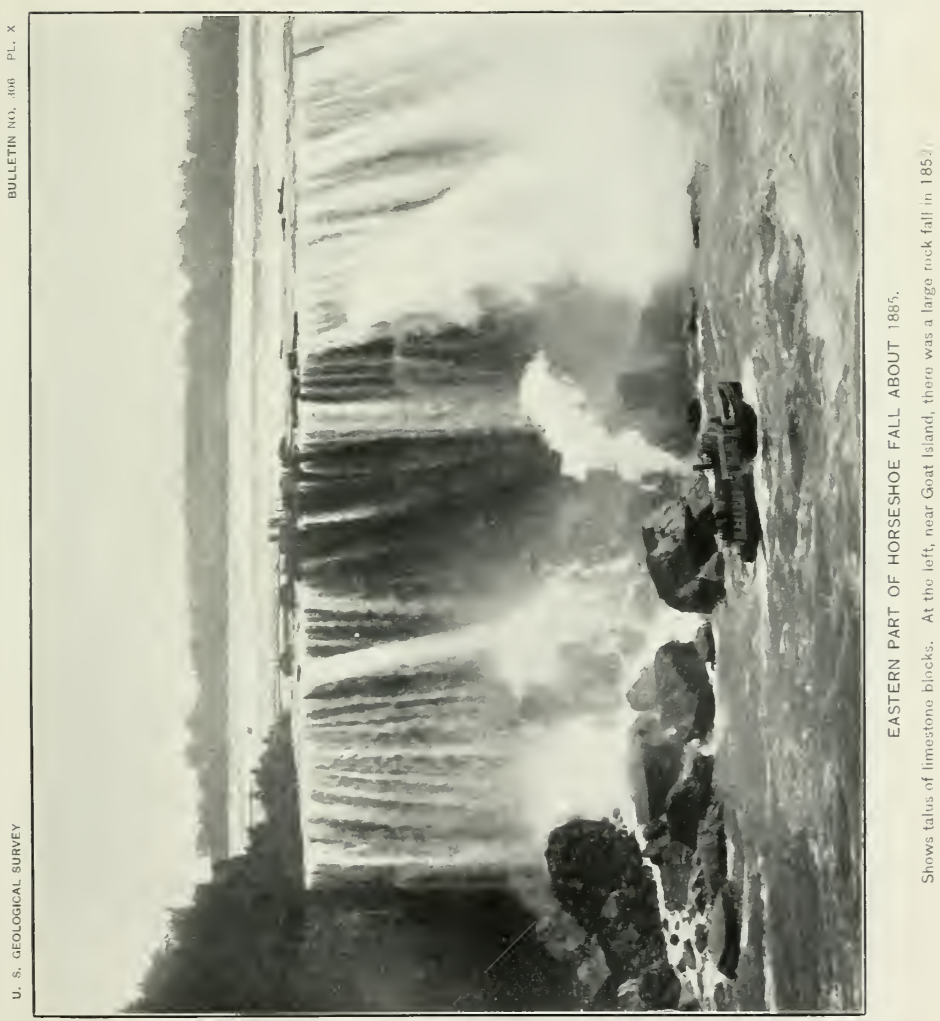





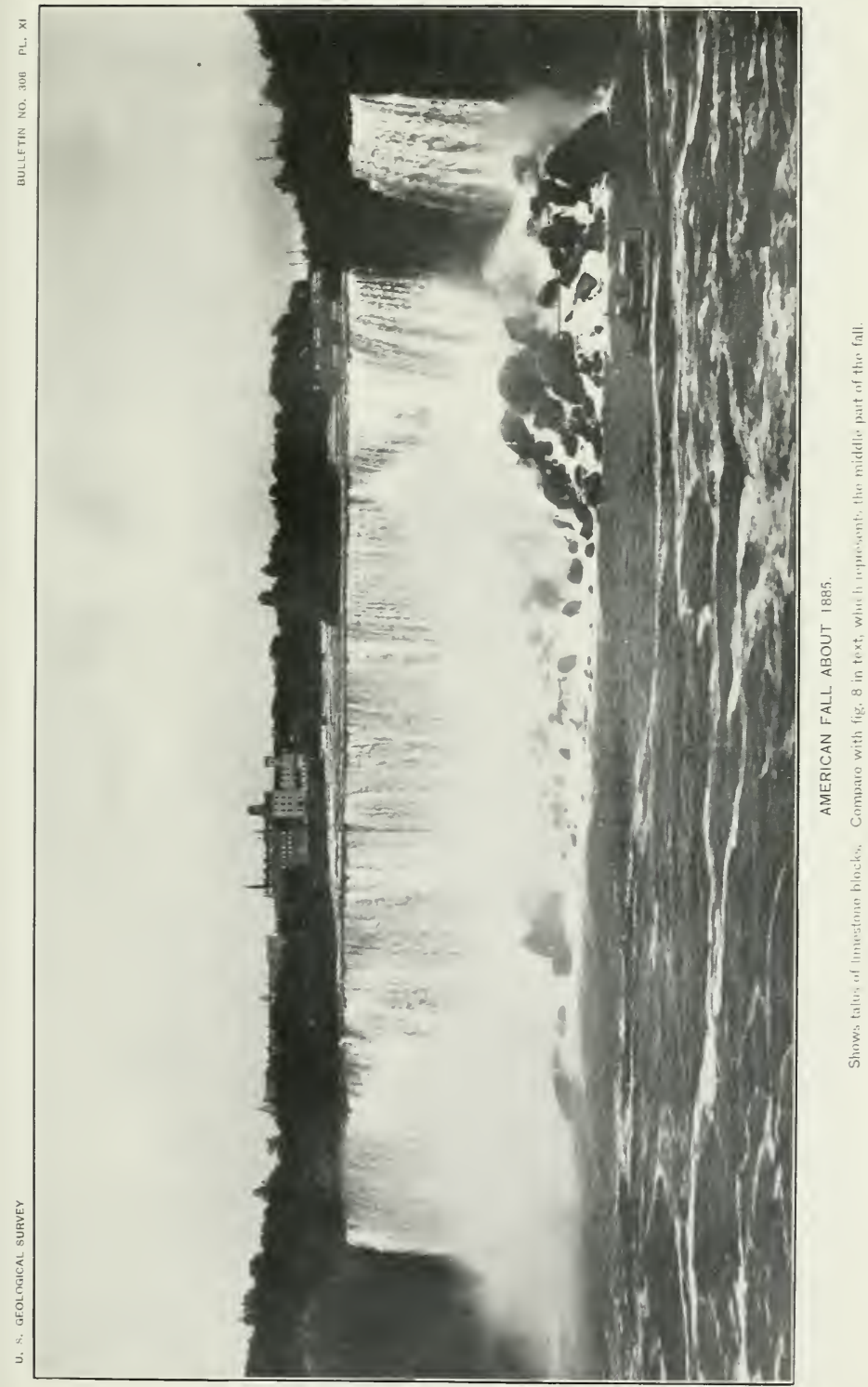



on the gradual encroachment of the protective talus upon the exposed cliff of shale, so that during the earlier part of the period the retreat was more rapid than during the later part. The indication, therefore, is that the present rate of recession is considerably less than 0.32 foot per annum, a result in harmony with that based on the maps and sketches.

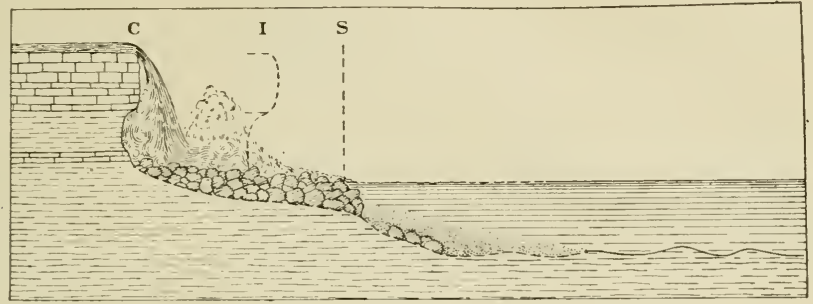

FIG. 8.-Profile and section of American Fall near its middle part. Compare fig. 1, also Pl. XI.

The assumptions underlying each of the estimates are factors of such importance that neither result can claim a high measure of precision. It appears to be safe to say that the present average rate of recession of the American Fall can not be so great as 0.5 foot per annum, and is probably as small as 0.2 foot per annum, or about one twenty-fifth of the rate of recession of the Horseshoe Fall.

\section{THE MAP OF 1842.}

The detection of an important error in the outline of the American Fall as mapped in 1842 tends naturally to bring in question all other results of the survey of that year. Inasmuch as the outline of the Horseshoe Fall as determined in 1842 is one of the most important lata used in the computation of the rate of recession, it has been subjected to critical examination and all practicable checks have been applied.

The framework of the survey includes two stations or "trigonometrical points" on the American shore, three on Goat Island, and three on the Canadian shore. Those on Goat Island were connected, each with the next, by traverse lines, distances being measured by the surveyor's chain and courses observed by the surveyor's compass; so also were the two on the American shore. All other connections were made by compass bearings. From the 7 stations thus established the positions of 29 points on the crest lines were determined by intersections of compass bearings. In all the later surveys the bearings were presumably made with the engineer's transit or the plane-table alidade, instruments susceptible of much higher precision than the surveyor's compass; but in view of the shortness of the 
distances the relative weakness of the surveyor's compass does not seem to me an important factor.

The stations and other points are indicated on the published map, and there is a "table of observations." With the aid of these data positions of points on the crest lines were replotted as a check on the accuracy of the compilation and engraving of the map. This work revealed three errors in the bearings as published, probably to be ascribed to copying or printing and not affecting the map. It indicated also that the points of the crest lines determined by intersection are not all accurately placed on the map, the errors a mounting usually to a few feet, but not affecting the computed rate of recession.

Each of the crest-line points was originally located, as a rule, by the intersection of two bearings, but there are four points to which three bearings were taken. In the replotting of these points the check afforded by the third bearing was found to give a satisfactory result. The points which have the advantage of this check are all on the east side of the Horseshoe curve, and include the point at the angle of the Horseshoe in the position where the notch subsequently developed ( $\mathrm{Z}$ in fig. 4, p. 14). For the remainder, or western part, of the Horseshoe curve there is no similar check, and the three located points of the crest line are so far apart as to give little mutual support. So far as the published data are concerned, these have no higher intrinsic authority than the two points on the American Fall which have been discredited by independent evidence.

The record of the Horseshoe Fall which stands nearest in time to the map of 1842 is Basil Hall's sketch from the Forsyth Hotel (Pl. III, p. 15), the interval being fifteen years. The general form of the crest line is the same in map and sketch, and the tangent based on the sketch is so related to the mapped crest line (fig. 4, p. 14) as to indicate some recession between the dates of the sketch and the map, but the amount of recession is less than would be expected.

The factors bearing on the estimate of the rate of recession are not so related that rigid mathematical methods can be applied to their discussion. The conflict of data and the mutual support of data can be weighed only by nonmathematical methods, and the result of their study is an opinion rather than a decision. The general tenor of the eridence, including the five surveys and the Basil Hall sketch, leaves no question that the annual rate of recession has been about 4 or 5 feet. If full authority be ascribed to the map of 1842, the estimated annual rate of recession is 5.3 feet. If full authority be ascribed to the tangent line based on the sketch of 1827 , the estimated rate is about 1 foot less. It is my opinion that the map affords the better record. Giving to it the greater weight and to the tangent a smaller weight, I think the best practicable estimate of the rate is between 5.3 and 4.2 feet, but nearer to the former; and I select 5 feet partly 
because a statement in even feet avoids the implication of high precision which might be suggested by a decimal. As an estimate of the average rate of recession during the period of definite observation, I think this can not be in error more than 1 foot.

\section{SLMUARY ANI CONCLUSION.}

The data for computing the rate of recession of Niagara Falls include surveys of the crest line made in $1 \$ 42,1875,1886,1890$, and and 1905 , and camera-lucida sketches made in 1827 . During the period covered by these data the local conditions affecting the rate of recession have not differed to an important extent from the natural conditions. The present and prospective diversions of water for economic uses interfere with the course of nature and may be expected to modify the rate of recession. The natural rate of recession of the Horseshoe Fall is desired by geologists in connection with estimates of the age of the river. The geologic bearing of a rate modified by human agency is less direct. The rate of recession of the American Fall is of interest to geologists because somewhat representative of the river's activity in gorge making when the volume of water was much less.

The rate of recession of the Horseshoe Fall, or the rate of lengthening of the Niagara gorge, during the sixty-three years from 1842 to 1905 is found to be 5 feet per annum, with an uncertainty of 1 foot. For the thirty-three years from 1842 to 1875 the rate was apparently slower than for the thirty years from 1575 to 1905 . The rate of recession of the American Fall during the seventy-eight years from 1827 to 1905 was less than 3 inches per annum.

The time consumed in the recession of the falls from the escarpment at Lewiston to their present position, or the age of the river, is not here estimated. It can not properly be computed without taking account of all conditions, local and temporary, affecting the rate of recession, and some of those conditions have varied greatly from point to point and from time to time. 


\section{REPORT OF SURTEY OF CREST LINE OF NIAG.ARA FALLS.}

\section{By IT. Carvel Hall.}

In obedience to instructions from Mr. H. M. Wilson, geographer of the United states Geological surver, issued in consequence of a plan of cooperation with Mr. Henry A. Tan Alstyne, state engineer of New York, a survey of the crest line of Niagara Falls was made by me in June. 1905. The determination of the present crest line of the falls was desired in order that, by comparison with maps of earlier dates, the changes could be determined and the rate of recession computed.

Survers of the falls of which we have record have been made as follows: In 1542, under the direction of Prof. James Hall, State geologist of New York; ${ }^{a}$ in 1si5, by the Lnited States Lake Survey, published in the form of a chart on the scale of $1: 2,500 ;{ }^{b}$ in $18 \times 6$, by Prof. R. S. Woodward, then chief geographer of the Enited States Geological Surrer: ${ }^{c}$ and in 1 1s90, by Mr. 1. S. Kibbe, assistant engineer, under the direction of Mr. John Bogart, State engineer of New York. ${ }^{d}$ A surrey was also made in 1904 by the Electrical Derelopment Company and Prof. J. IT. Spencer, but the map is not yet published.

The great majority of the monuments recovered or established by Mr. Kibbe in his survey of 1590 were found to be in good state of preserration, but a few, one unfortunately an important one, have disappeared. Appended hereto are tables giring descriptions of the various monuments recorered or used, together with their coordinates and the distances between them. In addition to these, there were used in the work temporary stations at Prospect. Point, Hennepin View, Stedman Bluff, Rock of Ages, center of south chord of the steel arch bridge, and the cupola of Table Rock House.

In the survey of 1542 the relations of a few points were fixt by trarersing with compass and chain, and the remainder of the work was done by compass, the positions of points on the crest being determined by intersection. In the survers of 1575,1856 , and 1890

a See Nat. Hist. of New York, pt. 4. Geology 1s43. pp. 402-404.

$b$ Listed by the Lake Surrer as Chart No. $4^{4}$

c Results published in Serenth An 2 . Rejt. Comrs, of St ute Reservation at Niagara, Alhany. 1n91.

I I dem. 
directions were observed by transit instead of compass. In the 1904 work an ingenious method was used, suggested, it is thought, by Mr. Goodwin, of the Electrical Development Company. He carefully measured the elevation of the crest of the falls and also of certain triangulation points on the Canadian bluff. Then, observing at the same instant for direction and for the amount of the "dip-angle," he computed the distance from point of observation to the crest at various places.

Any of these methods seems quite suitable for the determination of the crest at well-marked points, but the upper curve of the Horseshoe Falls has no well-marked points for observation, besides being masked by spray, and the methods adopted require considerable computation and use mainly descriptive matter' for identifying even the most important features. As stated by Professor Woodward in his report already referred to-

The points on the crests of the Falls determined by the 1856 survey varied considerably in respect to clearness of definition and ease and precision of fixture. Some of them were well defined exposures of bare rock; some were less well-defined portions of rock seen through the curved sheet of falling water; some were indentations in such sheets, well defined from any point of view but presenting different, aspects from different points of view; and sone were ephemeral sprays whose identification from different points of view was a matter of difficulty. * * * the probable error on the crest line does not on the average exceed \pm 1.5 feet. I much greater probable error must be assigned, howerer, to the upper part of the Horseshoe Falls.

Mr. Kibbe in his 1890 report states that "for tavorable locations on the crest of the Falls the probable error is \pm 1.0 foot, while along the deep-water portion of the Horseshoe Falls it may be somewhat greater."

In view of these facts, a different method was adopted in making the present survey, namely: T. P. No: 1 (at Prospect Point) and "Terrapin" (at Terrapin rocks) were accepted from Mrr. Kibbe's survey as initial points, and were plotted to a scale of 1 inch $=200$ feet on a plane-table sheet. From these as a base all existing triangulation points were relocated, and with some newly selected points formed the basis of the survey. Along the American Falls and at the ends of the Horseshoe Falls, hy means of photographs and careful descriptions, numerous features were recognized, intersected, and plotted, and the details of the map were continuously compared with the corresponding natural features and their positions checked. Thus any discrepancy between earlier surveys and the present work were at once seen and examined and were thoroly tested and proved before the work was accepted, the majority of locations being determined from six to eight stations. For the upper portion of the Horseshoe Falls a 30-inch searchlight of very high candlepower, partially masked, was used to mark on the crest of the falls successive small brilliant spots of light, which were simultaneously 
located by four transits and which it is believed should result in an accurate demarcation of that part of the crest.

An anomalous condition of affairs appears to be disclosed by the survey, similar to that noted in earlier work, riz, that certain points on the crest line have advanced instead of receded. This has heretofore been explained as due to discrepancies in the field work or inaccuracies in the delineation of the crest line between determined points. Doubtless these explanations hold good in all the surveys, past as well as present, but there is one cause of advancement and ultimate recession which does not appear to have been commented on, and which, after close questioning of numerous old residents and careful examination of the situation, I think is a very active element. It might here be emphasized that by the plane-table method used any discrepancy occurring was at once noticed and the new position most carefully checked.

In addition to the erosion caused by the spray and the chemical action of the water on the underlying shales, there is a well-marked change in the crest line, due to the forcing off of large blocks of rock from the crest itself.

Approximately 20 feet below the upper level there is a waterbearing seam in the limestone, particularly well marked at Goat Island and above the Ontario Power Company's new power house. I am informed that in the winter immense icicles form from this seam at various points where it is not noticeable in summer, owing to the quick evaporation. At about this same elevation there are at present on the American Falls four secondary cascades, or, as termed by the late Thomas $V$. Welch, superintendent of the state reserration, "bustles." In my judgment these can only have been caused by the slipping off of a mass of rock from the crest, sliding to some extent on the water-bearing seam and gradually prest out by the force of the water and ice in slowly widening cracks upstream till, overbalancing, they fall, learing the "bustles." The present surrey, I believe, has caught some of these masses as they are being forced out.

This theory was discust with a number of the best-informed inhabitants, and while ther agreed that large blocks did occasionally fall from the crest, instancing several examples, they claimed that in each case the fall was a sudden one, unaccompanied by any previous pushing forward of the mass. This forward motion, however, must be a rery slow one, and would not be noticed, while the final fall of the rock would be assumed to be the beginning and end of the action.

The accompanying plan of the survey (Pl. II, p. 10) shows the existing erest line by a solid line broken only where the flow of water is interrupted by overhanging rocks, and shows the earlier surveys by 
means of broken lines. Only those triangulation points which are permanently marked are indicated. The shore lines and the various permanent buildings are a compilation of all the records.

In the last few years the brink of the falls has been eurtailed on the Canadian side by a wall 495 feet long, completely shutting off the water for that distance, and thereby reducing the length of the Horseshoe Falls by about one-sixth. In recent rears five power companies have spent large sums of money to divert a portion of the water now flowing over the falls to their power houses, the total power at present chartered being about one-fifth of all available.

I desire to acknowledge my indebtedness for material assistance rendered in the work to $\mathrm{Mr}$. Edward H. Perry, superintendent of the State reservation at Niagara; to Mr. James Wilson, superintendent of the Queen Victoria Niagara Falls Park; to Mr. B. F. R. Paine, general manager of the Ontario Power Company, and to Mr. J. W. Kellogg, manager of the marine sales department of the General Electric Company.

TABLES.

The first of the following tables includes artificial monuments and other permanent reference points connected with the triangulations of the surveys. The designation, description, and location of each are given, together with its coordinates as referred to Topographic Point No. 1 of the survey of 1s42. The coordinates, with the exception of Semaphore, are taken from Mr. Kibbe's table in the Serenth Annual Report of the Commissioner's of the State Reservation at Niagara, pages 105 to 107 . 


\section{List of permanent reference points.}

Designation.

T. 1. No.1.

1842, 1s(x), 19x(15. Stone nonument 5 inches square on l'rospect Point 1 inch lelow sod. 13s feet from southwest corner stone house at bead of incline. 145 feet from northwest corner of same. and 15 feet from iron lamppost.

M ......... 1590, 19615. Stone monument 5 inches square, 1 foot below surface, with b-inch terra-cotta tile over it, set on hlu'f in ext reme edge of grarel walk at Porters Bluff, just east of path to the Terrapin Rocks.

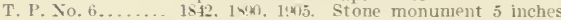
square. in path following top of biuff along southern shore of Goat island. This monument projects about 7 inches and is marked "6" on side.

Terrapin.

$15 \times 6,1590,1975$. Brass bolt 1 inch in diameter set in prominent square rock about 4 feet high, "word "Terrapin" cut in top of rock at end of wooden walk to platform where Terrapin Tower formerly stood. Beliered to coincide vers nearly with point used in 15,25

Loret to ........... 1856,1891.1905. Cross surmounting cupola of Loretto Convent also brass serew one-half inch in diameter in the deck of cupola directIs under center oi cross.

V. ....... 1890, 1905. Brass bolt 1 inch in diameter negr superintendent's office. Canadian side, set in the rock 1 foot under surface of lawn and surrounded by 4 -inch terra-cotta tile. 34.9 feet from southwest corner main building and 18.3 feet from southeast corner same.

B. 1690,1975 . Brass bolt 1 inch in diameter set in rock hetween pipe railing and brink. in Canadian resorvation, 30.2 feet from northeast corner of railing at " Ramblers Rest."

1ง90. 1905. Stone monument 6 inches square between pipe ralling and brink, in Canadian reservation. 25.4 feet northerly from pipe of drinking fount ain south of "Ramblers Rest." 1890.1905 . Stone monument 6 inches square. bet wcen pipe railing and brink, in Canadian reservation, a little south of ' Inspiration Point."

1890. 1905. Stone monument 6 inches square, marked ' I " on side, set in promiment projecting point at top of hluff on Canadian side about 317 fect southeasterly from south gable of Ontario power house, now in course of construction (June, 1905).

1500. Stone monument like last, about 400 feet southwardiy along bluff.

K .............. 1600). 1890. Stone monument like last, about $4(\mathrm{~m})$ feet southwardly along bluff.

L..........................

Semaphore........ Center of S-inch iron pipe sunk several feet it the ground on west bank railway cut about opposite Clarke Springs.

O.............. 1890. Stone monument 6 inches square set into slope at Stedmans Bluff; corered in 1900 by dry stone wall; references as on line between T. P. Yo. 1 and a nail in root of large leaning oak tree 21.41 feet southwest and 49.7 feet from nail in root of basswood tree.
Coordinates.

S. $1,929.1$

W.. $1,206.5$

S. $2,3 \overline{7}(1, \overline{7}$ W. $9(2), 4$

S. $2,044.2$ W. $1,465.5$

S. $3,671.4 \quad$ W. $3,623.4$

N. $1,021.9 \quad$ W. $1,462.1$

N. TX. 5 WI, $1,451.8$

N. 193.9 W. $1,751.6$

S. 455.2 W. $2,090,4$

S. $1,602.5$ W. $2,773.2$

S. $1,934.7 \quad$ W. $2,996.2$

S. $2,338,0 \quad$ W. $3,261.3$

S. $2,490,6 \quad$ IV. $3,507.2$

S. 989.1 W. 597.1 


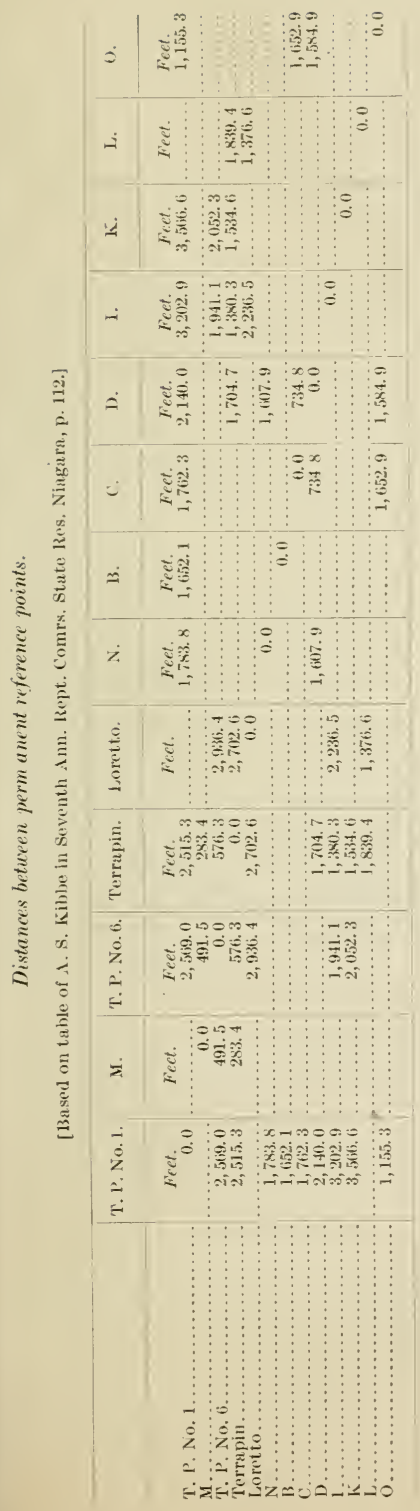





\section{CLASSIFICATION OF THE PUBLICATIONS OF THE UNITED STATES GEOLOGICAL SURVEY.}

[Bulletin No, 306.]

The publications of the Uniter States Geological Survey consist of (1) Annual Reports, (2) Ionographs, (3) Professional Papers, (4) Bulletins, (5) Mineral Resources, (6) Water-Supply and Irrigation Papers, ( 7 ) Topographic Atlas of Cnitec States-folins and separate sheets thereof, (S) Geologic Atlas of Uniterl Statesfolios thereof. The classes numbered 2,7 , and 8 are sold at cost of publication; the others are distributed free. A circular giving complete lists ean be had on application.

Iost of the above pulblications can be obtained or consulted in the following ways:

1. A limited number are deliveren to the Director of the survey, from whom they ('an he obtained, free of charge (except classes 2,7 , and 8 ), on application.

2. A certain number are delivered to senators and Representatives in Congres: for distribution.

3. Other copies are depositerl with the Superintendent of Documents, Washington, D. C., from whom they can le harl at prices slightly ahore cost.

4. Copies of all Government publications are furnisherl to the principal public libraries in the large cities thruout the Eniterl states, where they can be consulted by those interested.

The Professional Papers, Bulletins, and Water-Supply Papers treat of a variety of subjects, and the total number issued is large. They have therefore been classified into the following series: A, Economic geology; B, Descriptive geologr; C', Srstematic: geology and paleontology; D, Petrography and mineralogy; E, Chemistry and physies; F, (reography; G, Miscellaneous; H, Forestry; I, Irrigation; J, Water storage; K, Pumping water; L, Quality of water; II, General hydrographic investigations; $\mathrm{N}$, Water power; O, Cnderground waters; P, Iydrographic prouress reports. This paper is the one hundred and ninth in Series B, and the fifty-fourth in Series F, the complete lists of which follow ( $\mathrm{PP}=$ Professional Paper; $\mathrm{B}=$ Bulletin; WS $=$ Water-Supply Paper).

SERIE- B, DESCRIPTIVE GEOLOGY.

B 23. Observations on the junction between the Eastern sandxtone and the Keweenaw series on Keweenaw Point, Lake Superior, by R. D. lrving and T. ('. Chamberlin. 1 1 w. 124 pp., 17 pls. (Out of stock.)

B 33. Notes on geology of northern (alifornia, by J. S. Diller. 1kst. 23 pp. (Ont of stock.)

B 39. The upper beaches and Jeltas of Glacial Lake Agassiz, by Warren I"pham. 1.87. 81 pp.. 1 pl. (Out of stock.)

B 40. Changes in river courses in Washington Terrilory due to glaciation, by Bailey Willis. 1857. 10 pp., 4 pls. (Out of stock.)

B 45. The present condition of knowledge of the geology of Texas, by R. T. Hill, 1sti. 94 pp. (Out of stock.)

B 53. The geology of Nantueket, by X. S. Shaler, 1859. 55 pp., 10 pls, (()ut of stock.)

B 57. A geological reconnaissanee in southwestern Kansas, by Iobert Hay. 1890. 49 pp., 2 pls.

B 5s. The glacial boundary in westeru Pennsylvania, Ohio, Kentucky, Indiana, and Illinois, by G. F. Wright, with introluetion by T. C. Chamberlin. I890. $112 \mathrm{pp} ., 8$ pls. (Out of stock.)

B 67. The relations of the traps of the Newark system in the New Jersey region, by X. H. Darton. 1890. \$2 pp. (Out of stock.)

B 104. Glaciation of the Yellowstone Valley north of the Park, by W. H. Weed. 1k93. 41 pp., 4 jls.

B 108. A geological reconnaissance in central Washington, by I. C. Russell. 1893. 108 pp., 12 pls. (Out of stock.)

Bull. 306-06-3 
B 119. A geological reconnaissance in northwest Wyoming. by $(\dot{x}$. H. Eldridge, 1894. 72 pp., 4 pls.

B 137. The geology of the Fort Riley Nilitary Reservation and vieinity, Kansas, by Robert Hay. 1896. $35 \mathrm{pp} ., 8 \mathrm{pls}$.

B 144. The moraines of the Jissouri Coteau and their attendant deposits, by J. E. Todd. 1*9ti. 71 pp., 21 pls.

B 158. The moraines of soutleastern South Inkota and their attendant deposits, by J. E. Todd. 1899. $171 \mathrm{pp} ., 27 \mathrm{pls}$.

B 159. The geology of eastern Berkshire County. Yassachusetts, by B. K. Emerson. 1sy9. 139 pp., 9 pls.

B 165. Contributions to the geology of Maine. hy H. S. Williams and H. E. Gregory. 1900. 212 pp., 14 pls.

Wi 70. Geology and water resources of the Patrick and Goshen Hole quadrangles in eastern Wyoming and western Nebraska, by G. I. Adams. 1902. 50 pp., 11 pls.

B 199. Geology and water resources of the Snake River Plains of Idaho, by I. ('. Russell. 1902. 192 pp., $25 \mathrm{j}] \mathrm{s}$.

P1 1. Preliminary report on the Ketchikan mining district, Alaska, with an introductory sketch of the geology of southeastern Alaska, by A. H. Brooks. 1902. 1:20 pp., 2 pls.

PP 2. Reconnaissance of the northwesteru portion of Seward Peninsula, Alaska, by A. J. Collier. 1902. 70 pp., 11 pls.

PP 3. (ieology and petrography of Crater Lake National Park, by J. S. Ibiller and H. B. Patton. 1902. 167 pp., 19 pls.

PP 10. Reconnaissance from Fort Hamlin to Kotzebue Sound, Alaska. by way of Dall. Kanuti, Allen. and Kowak rivers. by W. C. Mendenhall. 1902. $6 \times$ pp., $10 \mathrm{pls.}$

PP 11. Clays of the United States east of the Mississippi River. by Ifeinrich Ries. 1903. 298 pp., 9 pls.

PP' 12. Geolugy of the Globe copper district, Arizona, by F. L. Ransome. 1903. 168 fp., 27 pls.

P1' 13. Drainage modifications in southeastern Ohio and adjacent parts of West Virginia and Kentueky, by W. G. Tight. 1903. $111 \mathrm{pp} ., 17$ pls. (Out of stoek.)

B 20x. Lescriptive geology of Nevada south of the fortieth frarallel and adjacent portions of california, by.J. E. Spurr. 1903. 229 pp., 8 pls.

B 209. Feoligy of Ascutney Jountain, Vermont, by R. A. Daly. 1903. 122 pp., 7 pls.

Ws ix. Preliminary report on artesian basins in southwestern Idalw and sontheastern Oregon, by I. C. Russell. 1903. 51 pp., 2 pls.

PP 15. Mineral resources of the Mount Wrangell district, Alaska, by W. C. Mendenhall and F. C. Schrader. $1903.71 \mathrm{pp}, 10 \mathrm{pls.}$

PP'17. Preliminary report on the geology and water resource of Nebraska west of the one hundred and third meridian, by X. H. Darton. 1903. $69 \mathrm{pp} .43 \mathrm{pls}$.

B 217. Yotes on the geology of southwestern fdaho and southeastern (1regon. 1,y 1. C. Russell. 1903. 83 pp., 18 pls.

B 219. The ore deposits of Tonopal, Nevada (preliminary rejort). by J. E. spurr. $1903 . \quad 31$ pp., 1 pl.

PP 20. A reconnaisance in northern Alaska in 1901. by F. C. Schrader. 1904. 139 pp., 16 plk.

PP 21. The geology and ore deposits of the Bisbee quadrangle. Arizona, by F. L. Ransome, 1904. 168 pp... 29 pls.

WS 90. Geology and water resources of part of the lower James River Valley, sonth Ibakta, by J. E. Todd and C. M. Hall. 1904. 47 pp, 23 pls.

Pl'25. The copper deposits of the Eneampment district. Wyoming. by A. C. Siencer. 1904. 107 pp., 2 pls.

PP 26. Economie resources of the northern Black Hills, by J. D. Irving, with contributions by S. F. Emmons and T. A. Jaggar, jr. 1904. 222 pp., 20 pls.

PP 27 . A geological reconnaissance across the Bitterroot Range and Clearwater Mountains in Montana and Idaho, by Waldemar Lindgren. 1904. 122 pp., $15 \mathrm{jls}$.

P' 1 31. Preliminary report on the geology of the Arbuckle and Wichita mountains in Indian Territory and Oklahoma, by J. A. Taff, with an appendix on rejorted ore deposits in the Wichita Yountains, by H. F. Bain. 1904. 97 pp., 8 pls.

B 235. A geologieal reconnaissance across the Cascade Range near the forty-ninth parallel, by G. O. smith and F. C. Calkins. 1904. 103 pp.,4 pls.

B 236. The Porcupine placer district, Aiaska, by C. W. Wright. 1904.35 pp., 10 pls.

B 237. Igneous rocks of the Highwood Mountains, Montana, by L. V. Pirsson. 1904. 20s pp., 7 pls.

B 239. Economic geology of the Jola quadrangle, Kansas, by G. I. Adams, Erasmuth Haworth, and II. R. Crane. 1901. $\$ 3$ pp.. 1 pl.

PP' 32. Geology and underground water resources of the central Great Plains, by .. Fi. Darton. 1905. 433 pp., 72 pls.

Ws 110. Contributions to hydrology of eastern [nited States, 1904; M. L. Fuller, geologist in charge. 1905. 211 pp., 5 pls.

B 242. Geology of the Hudson Valley letween the Hoosic and the Kinderhook, by T. Nelson Dale. 1904. 63 pp., 3 pls.

PP 34. The Delavan lobe of the Lake Yichigan glacier of the Wisconsin stage of glaciation and associated pbenomena, by W. C. Alden. 1904. $106 \mathrm{pp} ., 15 \mathrm{pls}$. 
PP 35. Geology of the Perry Basin in sutheastern Maine, by (4. O. smith and bavid White. 1905. 107 pp., 6 pls.

B 243. Cement materials and industry of the United States, by E. C. Eckel. 19t5. 395 pp., 15 pls.

B 246. Zine and lead deposits of northeastern Illinois, by H. F. Bain, 1904. 56 pl., 5 pls.

B 247. The Fairhaven gold placers of seward Peninsula, Alaska, hy F. H. Moftit. 1905. k5 pl.., 14pls.

B 249. Limestones of southwestern Pennsylvania, by F. G. Clapp. 1905. 52 pp., 7 pls.

B 250. The petroleum fields of the Pacific coast of Alaska, with an aceount of the Bering River coal deposit, by G. C. Martin. 1905. 65 pp., 7 pls.

B 251. The gold placers of the Fortymile, Birch Creek, and Fairbanks regions, Alaska, by L. M. Prindle. 1905. $16 \mathrm{pl}, 16$ pls.

Wi 118. Geology and water resources of a portion of east-central Washington, by F. C. Calkins. 1905. $96 \mathrm{pp} ., 4 \mathrm{pls}$.

B 252. Preliminary report on the geology and water resources of eentral oregon, by I. ('. Russell. 1905. $13 \AA \mathrm{pp}, 2 \mathrm{t} \mathrm{pls}$.

PP 3ti. The lead, zine, and fluorspar deposits of western Kentucky, by E. O. I'lrich and W... Tangier Smith. 1905. $218 \mathrm{py}, 15 \mathrm{pls}$.

P' 3*. Eeonomic geology of the Bingham mining district of Ltah, by J. M. Boutwell, with a ehapter on areal geology, by Arthur Keitb, and an int roduction on general geology, by S. F. Emmons. 1905. 413 PP., 49 pls.

PP 41. The geology of the entral Copper River region, Alaska. by W. C. Mendenlall. 1905. 133 pp., 20 pls.

B 254. Report of progress in the geological resurvey of the Cripple Creek distriet, Coloralo, by Waldemar Lindgren and F. L. Ransome. 1904. 36 pp.

B 25.5. The fluorspar deposits of southern Illinois, by H. Foster Bain. 1905. 75 pp., 6 pls.

B 25t. Yineral resources of the Elders Ridge quadrangle, Pennsylvania, by R. W. Stone. 1905. 85 pp., 12 pls.

B 25i. Geology and Paleontology of the Juditb River beds, by T. W. Stanton and J. B. Hateher, with a chapter on the fossil plants, by F. H. Knowlton. 1905. 174 pp., 19 pls.

PP 42. Geology of the Tonopah miping district, Nevada, by J. E. Spurr. 1905. 295 pP., 24 pls.

W: 123. Geology and unlerground water conditions of the Jornada del Nuerto, New Yexieo, by C. R. Keyes, $1905 . \quad 42$ pp., 9 pls.

WS 136. Underground waters of Salt River Valley, Arizona, by W. T. Lee. 1905. 194 Pp., 24 pls.

PP 43. The copper deposits of Clifton-Norenci, Arizona, by Waldemar Lindgren. 1905. 375 pp., 25 pls.

B 265. Geology of the Boulder district, Colorado, by X. Y. Fenneman. 1905. 101 p., 5 pls.

B 267. The copper deposits of Missouri, by H. F. Bain and E. O. Clrich. 1905, 52 pp., 1 p].

PP 44. Inderground water resources of Long lsland, New York, by A. C. Veateh, and others. 1905. 394 pp., 31 pls.

Ws 148. Geology and water resources of Oklaboma, by 6. N. Gould. 1905. 17s pp., 22 pls.

B 270. The configuration of the rosk floor of Greater New York, by W. H. Hobbs. 1905. $96 \mathrm{pp}, 5 \mathrm{pls.}$

B 272. Taconic physingraphy, by T. M. Dale. 1905. 52 pp., 14 pls.

PP 45. The geography and geology of Alaska, a summary of existing knowledge, by A. H. Brooks, witlı a section on climate, by Clereland Abbe, jr., and a topographic map and description thereof, ly. R. M. Goode. 1905. 327 pp., 34 pls.

B 273. The drumlins of southeaslern Wisconsin (preliminary paper), by W. C. Aldell. 1905. 46 pp., 9 pls.

P1' 16. Geology and underground water resources of northern Louisiana and southern Arkansas, by A. C. Veatch. 1906. 422 pp., 51 pls.

PP 49. Feology and mineral resonrces of part of the Cumberland Gap coal field, Kentucky, by G. H. Ashley and L. C. Glenn, in cooperation with the State Geological Department of Kentuekr, C. J. Norwood, curator. 1906. 239 pp., 40 pls.

PP 50. The Montana lobe of the Keewatin ice sheet, by F. H. H. Callomn. 1906. 62 pp., 7 pls.

B 277. Mineral resources of Kenai Peninsula, Alaska: Gold fields of the Turnagain Arm region, by F. H. Moffit; and the coal fields of the Kachemak Bay region, by R. W. Stone. 1906.80 pp., 18 pls. (Out of stock.)

Wi 15t. The geology and water resources of the eastern portion of the Panlandle of Texas, by $c: x$. Gould, 1906. 64 pp., 15 pls.

B $27 x$. (ieolugy and coal resources of the Cape Lisburne region, Alaska, by A. J. Collier. 1906. 54 pp., 9 pls.

B 279. Mineral resources of the Kittanning and Rural Valley quadiangles. Pennsylvania, by Charles Butls. 1906, 198 pp., 11 pis.

B 2n0. The Rampart gold placer region, Alaska, by L. M. Prindle and F. L. Hess. 1906.54 pp, 7 pls. B 252. Oil fields of the Texas-Lonisiana Gulf Coastal Plain, by N. M. Fenneman, 1906. 146 pp., 11 pls. WS 157. Cnderground water in the ralleys of Utah Lake and Jordan River, Ctah, by G. B Richard. son. 1906. 81 pp., 9 pls.

PP 51. Geology of the Bıghorn Mountains, by N. H. Darton. 19u6. 129 pP., 47 pls.

Ws 158. Preliminary report on the geology and underground waters of the Roswell artesian area, New Mexien, by C. A. Fisher. 1906.29 p., 9 pls. 
['1' 52. Geology and underground water of the Arkansas Valley in eastern Colorado, by X. H. Darton. 1906. 90 pp., 2- pls.

W: 159. Summary of underground-water resumres of Mississippi, by A. F. Crider aud L. C. Johuson. 1906. si pp., 6 pls.

1'P 53. Geologr and water resonres of the Bighom basin. Wyoming. by Cassius A. Fisher. 190\%. $72 \mathrm{H} . .16 \mathrm{pls}$.

B 24. Geology and mineral resources oi Mississippi, by A. E. Crider. 1906. 99 pp., 4 pls.

B 2 6. Eeonomic geology of the Beaver quadrangle. Pennsylvania southern Bearerand northwestern Allegheny counties, by L. H. Wooloy. 1906. 132 pp., 8 pls.

B -2:- The Juneau gold belt. Alaska, by A. C. Spencer, and a reconnaissance of Admiralty lsland. Alaska, by C. II. Wright. 1906. 161 pp.. 37 pls.

PP 54. The geolngy and gold deposits of the Cripple Creek district, Culorado, by W. Lindgren and F. L. Ransome. 1906. - pp.. 29 pis.

PP 5.5. Ore deposits of the Silver Peak quadrangle. Nevada, by J. E. Spurr. 1906. 174 pp., 24 pls.

B 24y. A reennaiszance of the Matanuska coal field, Alaska, in 1905, by G. C. Martin. 1946. 36 pp., 5 pls.

W: 16. Inderground waters of Tenwesece and hentucky west of Tenneste River and of an adjacent area in IJlinois, br L, C. Glenu. 14xi. 173 pp., 7 pls.

B : 2.3. A reconnaisance of some gold and tin deposits of the southern Appalachians, br L. C. Groton. with notes on the Dahlonega mines, by W. Lindgran. 1906. 134 pp., 9 pls.

B 294. Zinc and lead deposit-of the upper Mississippi Valler, by H. Foster Bain. 1906. 155 pp.. 16 pls.

B 295. The Yukon-Tanana region. Alaska, description of eirele quadrangle, by L. M. Prindle. 19u6. 27 p p.. 1 pl.

B Hwi. Economic geology of the Independence guadrangle, Kansas, by Frank C. schrader and Erasmus Haworth. 1406. 74 pp. 6 pls.

W-1-1. Geology and water resures of Owens Valley. California, by Willis T. Lee. 1906. 28 pp., 6 pls.

B :97. The Yampa coal field, Rout County, Colo., by X. M. Fenneman, Hoyt - Gale. and II. R. Campbell. 1906. $96 \mathrm{pp} ., 9 \mathrm{pls}$.

B 300. Economic geology of the Amity quadrangle in eastern Washington County. Pa., by F. G. Clapp. 1906. - pp.. spls.

B 303. Preliminary account of Goldfield. Bullfrog. and other mining districts in southeru Yerada, by F. L. Ransome, with notes on the Manhattan district, by G. H. Garrey and W. H. Emmons. 1200. - pp. 5 pls.

B 304. Oil and gas fields of Greene County, Pa., by R. W. Stone and F. G. Clapp. 190.. - pp.. 3 pls.

W: 1 . Water resources of the Rio Grande Valler in New Mexico and their development, by W. T. Lee. 1906. - pp., 10 pls.

B 3h. Rate of recession of Niagara Falls, by G. K. Gilbert, accompanied by a repurt on the surver of the erest, by W. Carvel Hall. 146\%. 31 pp., 11 pls.

\section{SERIES F, GEOGRAPHY.}

[All are bulletins thus far except Profssejonal Paper 45.]

5. Dietionary of altiudes in Cnited states, br Henry Gaunett. 184. 325 pr. Out of stock; see Bulletin 2 $i$.

6. Elerations in Dominion of Canada, by J. W. spencer. 134. 43 pp. Out oi stock.

13. Boundaries of Cnited States and oi the several States and Territories, with historical sketeh of territorial changes, by Henry Gannett. 1-5. 135 pp. (Out of stock; see Bulletin 226.)

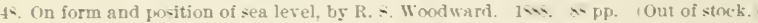

49. Latitudes and longitudes of eertain fuints in Misouri, Kansas, and Xew Mexico. by R. S. Wondward. 1‥ $133 \mathrm{pp}$. (Out of stock.

vi). Formulas and tables to facilitate the eonstruction and nee of mays, by R. = Woolward. 1wa. 124 pp. Out of stock.

70. Report on astronomical work of 1 wa and 1640 , by R. S. Woodward. $1890.79 \mathrm{pp}$.

72. Altitude between Lake siperior and Rocky Monntains, by Warren Cpham. 1691. 229 pp.

76. Dietionary of altitudes in tnited States second edition. by Henry Gannett. 1891. 393 pp. (Uut of stock; see Bulletin 2-it

115. Geographic dietionary of Rhode Island, by Henry (jannett. 1694. $31 \mathrm{pp}$.

116. Geographic dictionary of Massachuset ts, ly Henry Gannett. 1s91. $126 \mathrm{pp}$.

11. Geographic dictionary of Connecticut, by Henry Gaunett. 1894. 67 pp.

118. Geographic dictionary of New Jerey. by Henry Gannett. 1894. $131 \mathrm{pr}$.

122. Results of primary triangulation, by Henry Gannett. 1s44. $412 \mathrm{pp} .17$ pls. (Out of stock.)

123. Dictionary of geographic positions. by Heury Gaunett. 159.5. $153 \mathrm{p}[$.. 1 map. (Out of stock.)

154. Gazetteer of Kansas, by Henry Gannett. 1 <as. 246 pp., 6 pls,

160. Dictionary of altitudes in Cnited states third edjtion), by Henry Gannett. 1899. 775 pp. (Out of stock. see Bulletin 274.)

106. Gazetteer of (tah, br Henry Gannett. 1900. 43 pp.. 1 map. (O)ut of stock.

169. Altitudes in Alaska, by Henry Gannett. 1900. $13 \mathrm{pp}$. 
170. Survey of boundary line between Idaho and Montana from international bolmdary to crest of Bitterroot Mountains, by R. U. Goode. 1900. 67 pp., 14 pls.

171. Boundaries of [nited states and of the several states and Territories, with outline of history of all important changes of territory (second edition), by Henry Gannett. 1900. 142 pI... 53 pls. (Out of stock; see Bulletin 226.)

174. Survey of northwestern boundary of [nited states, 14.57-1561, by Mareu- Baker. 1900. Ts pp., $1 \mathrm{pl}$.

175. Triangulation and spirit leveling in Indian Territory, by C. H. Fitch. $1900.141 \mathrm{pp} ., 1 \mathrm{pl}$.

181. Results of primary triangulation and primary traverse, fiseal year 1900-19:3, by H. M. Wilson, J. H. Renshawe, E. M. Douglas, and P. L. Goode. 1901. 240 Hp. 1 map.

183. Gazetteer of Porto Rico, by Henry Gannett. 1901. $51 \mathrm{pp.}$

185. Results of spirit leveling, fiscal year 1900-1901, by H. M. Wilson, J. H. Fienshawe, E. M. Donglas, and R. L. Goode. 1901. $219 \mathrm{pp}$.

187. Geographic dictionary of Alaska, by Hareus Baker. 1901. $446 \mathrm{pp.}$ (Out of stock.)

190. Gazetteer of Texas, by Henry Gannett. 1902. $162 \mathrm{pp}, 8 \mathrm{pls.} \mathrm{(Out} \mathrm{of} \mathrm{stock.)}$

192. Gazetteer of Cuba, by Henry Gannett. 1902. 113 pp.. \& pls. (Out of stock.

191. Northwest boundary of Texas, by Marcus Baker. 1902. 51 pp., 1 pl.

196. Topographic development of the Klamath ILountains, by J. S. Diller. 1902. 69 pp., 13 pls.

197. The origin of certain place names in the Lnited states, by Henry Gannett. 1902. 270 pp. (O)ut of stock; see Bulletin 258 .

201. Results of primary triangulation and primary traverse, fiseal year 1901-2, by H. II. Wilson, J. H. Renshawe, E. M. Douglas, and R. U. Goode. 1902. 164 pp., 1 pl.

214. Geographic tables and formulas, compiled by \$. . Gannett. 1903. 284 pp. (Out of stock; see Bulletin 234.)

216. Results of primary triangulation and primary traverse, fiscal year $1902-3$, by 8 . \&. Gannett. 1903. $222 \mathrm{pp} .1 \mathrm{pl}$.

224. Gazetteer of Texas (second edition), by Henry Gannett. 1904. 17i pp., 7 pls.

226. Boundaries of the Cnited states and of the several States and Territories, with an outline of the history of all important ehanges of territory (third edition), by Henry Gannett. 1904. 145 pp., 54 pls.

230. Gazetteer of Delaware, by Henry Gannett. 1904. 151 14.

231. Gazetteer of Maryland, by Henry Gannett. 1904. st jp.

232. Gazetteer of Virginia, by Henry Gannett. 1904. 159 py.

233. Gazetteer of West Virginia, by Heury Gannett. 1904. 164 pp.

234. Geographic tables and formulas (second edition), compiled by S. S. Gannett. 1904. 310 pp.

245. Results of primary triangulation and primary traverse, fiscal year 1902-3, by S. S. Gannett. 1904. $328 \mathrm{pp} ., 1 \mathrm{pl}$.

248. Gazetteer of Indian Territory, by Henry Gannett. . 1904. 70 pp:

258. The origin of eertain place names in the United states (second edition), by Henry Gannett. 1905. $334 \mathrm{pp}$.

Protessional Paper 45. The geography and geology of Alaska a summary of existing knowledge, by $\mathrm{A}$. H. Brooks, with a section on climate, by cleveland Abbe. jr.. and a topographic map and description thereof, by R. U. Goode. 1906. $327 \mathrm{pp}, 34 \mathrm{pls}$

274. A dietionary of altitudes in the Cnited states (fourth edition), compiled by Henry Gannett. 1906. $1072 \mathrm{pP}$.

276. Results of primary triangulation and primary traverse, fiscal year $1904-5$, by S. S. Gannett. 1905, 263 pp.. 1 pl.

281. Results of spirit leveling in the state of New York for the years $1 \times 4$ to to 1905 , inclusive, by F... Gannett and D. H. Baldwin. 1906. 112 pp.

288. Resuits of spirit leveling in Pennsylvania for the years $1 \times 99$ to 1905 , inclusive, by $S . \therefore$. Gannett and D. H. Baldwin. 1906. $62 \mathrm{IP}$.

291. Gazetteer of Colorado, by Henry Gannett. 1906. 1×5 1p.

299. Geographic dietionary of Aluska, by Mareus Baker: seeond edition, prepared by James McCormi $\cdot k$. 1906. $690 \mathrm{pp}$.

302. Areas of the Lnited States, the States, and the Territories, by Henry Gannett. 1906.9 pp., 1 pl.

306. Rate of recession of Xiagara Falls, by G. H. Gilbert, aceompanied by a report on the survey of the crest, by W. C. Hall, 1906. 31 pp., 11 pls.

Correspondence should be addrest to

THE IMIRECTOR,

[Xited states Geological sirrey, IV Ashixgtox, D. C.

DECENBER, $190 \mathrm{C}$ 





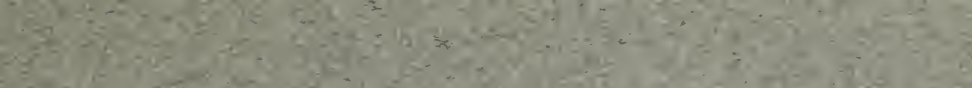

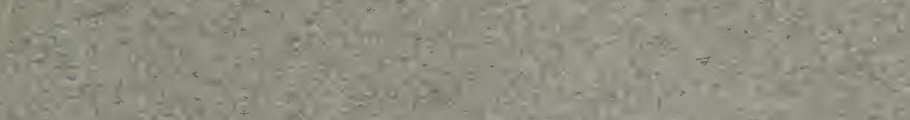

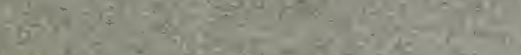

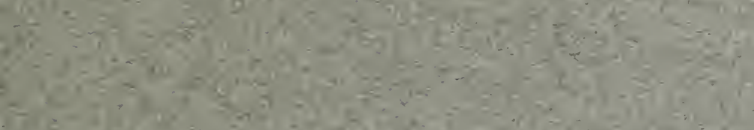

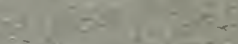

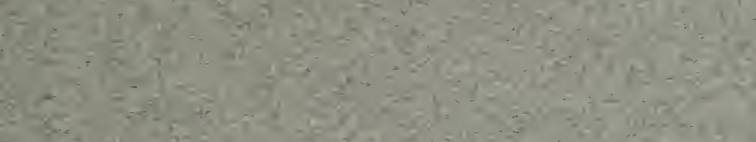

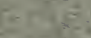

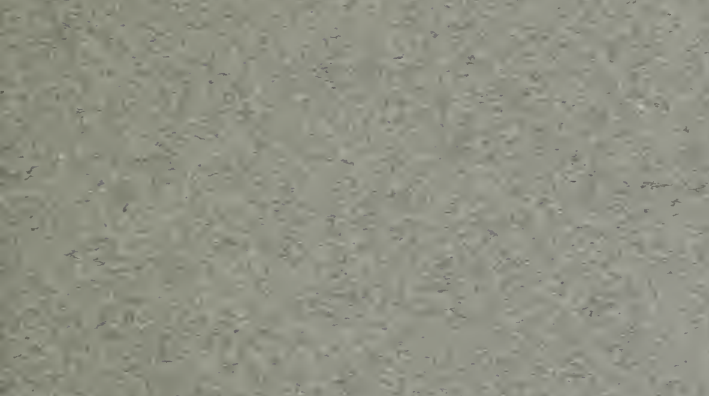

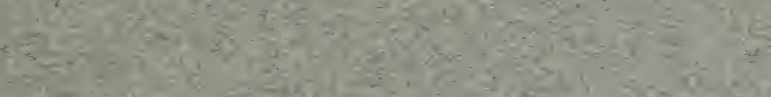
For

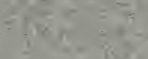

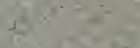

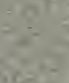

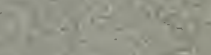
$\frac{1}{2+1}$

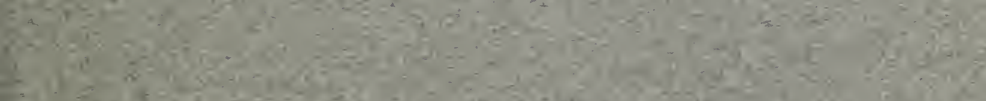

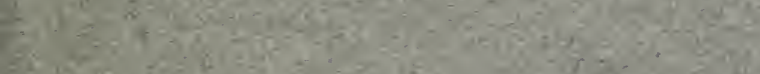





SPCL $\quad F \quad 127$ N8 G46

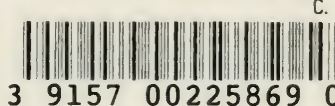

$S_{p} \subset 1$

186081

F

127

N 8

BROCK UNIVERSITY

G 46 ST. CATHARINES, ONTARIO

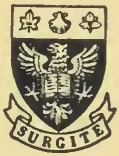

LIBRARY 
